\title{
Is the Relationship between Financial Development and Economic Growth Monotonic? Evidence from a Sample of Middle Income Countries*
}

\author{
Nahla Samargandi ${ }^{\dagger}$, Jan Fidrmuc ${ }^{\star}$ and Sugata Ghosh ${ }^{\S}$
}

\begin{abstract}
We revisit the relationship between financial development and economic growth in a panel of 52 middle-income countries over the 1980-2008 period. Using pooled mean group estimations in a dynamic heterogeneous panel setting, we show that there is an inverted U-shaped relationship between finance and growth in the long-run. In the short run, the relationship is insignificant. This suggests that too much finance can exert a negative influence on growth in middle-income countries. The finding of a non-monotonic effect of financial development on growth is confirmed by estimating a threshold model.
\end{abstract}

Keywords: Financial development; economic growth; pooled mean group estimation; dynamic panel threshold; non-monotonicity.

JEL Codes: C23, O11, O16, O47.

\footnotetext{
${ }^{*}$ We are grateful to David Giles, Yiannis Karavias and Mohammad Tajik for providing us with the codes for some of the tests used in this paper. We benefited from the helpful comments and suggestions received from Dirk Bezemer, Dimitris Christopoulos, John Duca, Markus Eberhardt, Bruce Hansen, Halvor Mehlum, Vinod Mishra, Hashem Pesaran, Romain Ranciere, Ron Smith, Russell Smyth, as well as workshop and conference participants at Brunel University, the 75th International Atlantic Economic Conference at the University of Vienna, and the 2014 Conference of the Financial Engineering \& Banking Society at the University of Surrey. We are most grateful to three anonymous referees and to the Editor-in-Chief for the constructive comments and suggestions that helped to improve our paper. We are solely responsible for any errors that may have remained. Nahla Samargandi's research on this article was supported by a PhD scholarship from King Abdul Aziz University, whose financial support she would like to gratefully acknowledge.

${ }^{\dagger}$ Department of Economics and Finance, Centre for Economic Development and Institutions (CEDI), and Brunel Macroeconomics Research Centre (BMRC), Brunel University; and Department of Economics, Faculty of Economics and Administration, King Abdulaziz University, Saudi Arabia; E-mail: nsamrgandi@kau.edu.sa.

ॠCorresponding Author: Department of Economics and Finance and Centre for Economic Development and Institutions (CEDI), Brunel University; Institute of Economic Studies, Charles University; and CESifo Munich. Contact information: Department of Economics and Finance, Brunel University, Uxbridge, UB8 3PH, United Kingdom. Email: Jan.Fidrmuc@ brunel.ac.uk or jan@ fidrmuc.net. Phone: +44-1895-266-528, Web: http://www.fidrmuc.net/.

$\S$ Department of Economics and Finance, Centre for Economic Development and Institutions (CEDI), and Brunel Macroeconomics Research Centre (BMRC),, Brunel University, UK; Email: sugata.ghosh@brunel.ac.uk; Tel: +44 1895 266887.
} 


\section{Introduction}

The relationship between financial development and economic growth is important and intriguing at the same time. The earliest known proponents of the notion that finance could be an engine of growth are Schumpeter and Opie (1934); their view was later endorsed by Gurley and Shaw (1955), McKinnon (1973) and Shaw (1973), among others. There is, however, another strand of the literature that dates back to Robinson (1952), arguing that economic growth drives the demand for financial services rather than the other way round. Finally, some economists, like Lucas (1988), discount altogether the possibility that the financial sector has any impact on growth. The importance of financial deepening in channeling savings to the most productive investments and shaping the growth process has received renewed attention as the endogenous growth literature evolved from the 1980s onwards (see Greenwood and Jovanovic, 1990; Bencivenga and Smith, 1991; King and Levine, 1993a; etc.). The strength of the finance-growth relationship can perhaps be regarded as ultimately an empirical matter (King and Levine, 1993b; Levine, 2005), and much of the subsequent literature has focused attention on the empirical aspects of this relationship by considering various data-sets, country groupings, time periods, etc., and different indicators of financial development, and using a whole host of econometric techniques. $^{5}$

With this backdrop, we attempt in this paper to contribute to the finance and growth literature by studying this relationship for a group of middle-income countries, using advanced econometric techniques. In doing so, we explore the nature of the relationship between financial development and economic growth, and especially consider whether it may in fact be non-monotonic. Indeed, much of the current literature suggests that the impact of financial deepening on growth becomes negative once a certain threshold is reached (Arcand et al., 2012; Cecchetti and Kharroubi, 2012), or that this impact seems to have evaporated in recent data (Rousseau and Wachtel, 2011).

In the light of the on-going debate on the impact of financial development on economic growth, we seek to contribute to the literature - from an empirical perspective - in the following ways. First, we adopt the recently developed dynamic panel heterogeneity analysis introduced by Pesaran et al. (1999) and applied to the financial development and growth nexus by Loayza and Ranciere (2006). Specifically, we use the autoregressive distributed lag (ARDL) model, where the estimations are carried out by three different estimators: the pooled mean group (PMG), mean group (MG), and the dynamic fixed effect (DFE), in order to examine both the long- and short-term effects of financial

\footnotetext{
${ }^{5}$ A comprehensive literature survey on the topic is provided in section II of the paper.
} 
intermediation on growth. The use of these techniques allows us to take into account country-specific heterogeneity. Second, we consider 52 middle-income countries. ${ }^{6}$ Although there is a large body of literature that investigates the linkage between financial development and economic growth in advanced countries, far less is known about this relationship in developing countries. The focus on advanced countries is particularly due to the nature of their financial markets. Financial systems in advanced countries can efficiently facilitate the mobilization of capital between surplus and deficit agents, which eventually leads to economic growth. Developing countries, on the other hand, were traditionally characterized by less developed and less efficient financial systems with lower levels of banking intermediation. However, from the 1980s onwards, developing countries have improved the efficiency of their financial markets. Nonetheless, previous studies argue that the relationship between financial development and economic growth in developing countries is inconclusive (Kar et al, 2011). Third, given that financial development can be captured by several possible indicators, we use the principal component analysis (PCA) to construct an indicator of financial development that is as broad as possible and captures various dimensions of the financial sector. Finally, in contrast to Loayza and Ranciere (2006), we allow for the existence of a non-linear relationship between financial development and economic growth in order to investigate the possibility of the economy being adversely affected due to "too much" finance. Specifically, we apply two approaches: we introduce a quadratic polynomial of financial development as a determinant of growth, and estimate a threshold model. In the former, we test the robustness of our results by following the recent study by Lind and Mehlum (2010), which proposes tests for the existence of $U$ or inverted U-shaped relationships. By applying this test, both necessary and sufficient conditions for the existence of an inverted U-shaped pattern can be verified. $^{7}$ As regards the second approach, we follow Bick (2010) and Kremer et al. (2013) and estimate a dynamic panel threshold model that accounts for sharp discrete shifts to investigate the potential existence of a threshold level in the linkage between financial development and economic growth. To our knowledge, this is the first study that combines these two different approaches to investigate the non-linearity within the finance and growth nexus.Our findings therefore suggest that the relationship between financial development and economic growth need not be linear, either in the long or short-run. Rather, the two different techniques used confirm that financial deepening might have a negative effect on growth beyond a certain threshold, which is different from the predominant view that financial development and economic growth are positively linked.

\footnotetext{
${ }^{6}$ The World Bank classification in 2010 is considered here.

${ }^{7}$ An inverted U-shaped test by Lind and Mehlum (2010) will be discussed in detail in the results and discussion section.
} 
The remainder of this paper is organized as follows: Section II conducts an extensive survey of the literature on finance and growth to put our study in context. Section III discusses the data and describes the construction of the financial development indicator. Section IV explains the econometric methodology used to analyze the impact of financial development on economic growth. The empirical results of the paper are discussed in section V. Finally, Section VI concludes the paper.

\section{Literature Review}

In this section, we review the extensive literature on the relationship between finance and growth, which can be traced back to the early twentieth century. Among the initial influential contributions in this area is the work of Schumpeter and Opie (1934), who highlighted the role of financial institutions in funding productive investments and encouraging innovation, both of which foster growth. Patrick (1966) develops the ideas of 'supply-leading' and 'demand-following' aspects of financial development. The supply-leading role of financial institutions is to act as productive inputs in the production process and to transfer resources from traditional to modern sectors. This is echoed by Gurley and Shaw (1955) and Goldsmith (1969), who argue that more developed financial markets promote economic growth by mobilizing savings to finance the most productive investments. In a more recent study, $\mathrm{Xu}$ (2000) finds strong evidence that financial development, primarily via the investment channel, affects growth positively.

The demand-following role is about growth being spurred by the real side of the economy, which generates the demand for financial services so that financial institutions and instruments emerge to follow the lead taken by the real sector. ${ }^{8}$ More rigorous theoretical underpinnings to the financegrowth relationship were provided by McKinnon (1973) and Shaw (1973), who observed that pervasive financial regulations involving interest rate ceilings and reserve requirements, especially in developing countries, impede saving-investment decisions and stressed the importance of financial liberalisation via a deregulation of interest rates which would lead to an increase in loanable funds as well as to a more efficient allocation of funds. ${ }^{9}$

\footnotetext{
${ }^{8}$ The demand-following role of the financial sector is emphasised also by Robinson (1952) and Kuznets (1955). This view has also been endorsed by the empirical studies of Al-Yousif (2002) and Ang and McKibbin (2007), while Xu (2000) rejects this hypothesis.

${ }^{9}$ Calderon and Liu (2003) test the direction of causality between financial development and growth for a pooled dataset of 109 countries for 1960 to 1994 and find evidence of bi-directional causality between those variables using the Geweke decomposition test. Some evidence of bi-directional causality is also found by Luintel and Khan (1999) in a VAR analysis of 10 developing countries.
} 
With the emergence of endogenous growth theory (Romer, 1986; Lucas, 1988), there has been renewed interest in the role of financial development in driving economic growth. This literature highlights the positive role played by the financial sector in bolstering growth, in particular,by mobilizing savings, allocating resources to the most productive investments, reducing information, transaction and monitoring costs, diversifying risks and facilitating the exchange of goods and services. This results in a more efficient allocation of resources, a more rapid accumulation of physical and human capital, and faster technological progress. For instance, the theoretical work of Greenwood and Jovanovic (1990) shows that financial intermediaries promote investment and growth by enabling a higher rate of return to be earned on capital, while the growth itself spurs the expansion of financial institutions, implying a two-way relationship between financial intermediation and economic growth. Likewise, in Bencivenga and Smith (1991), financial intermediaries allow agents to channel savings into investments with high return which boosts growth, but here the intermediaries also allow individuals to hold diversified portfolios to mitigate risks associated with their liquidity needs. Roubini and Sala-i-Martin (199) show that in a situation where it is difficult to raise revenue via income taxation, governments may resort to financial repression to raise the inflation tax base to finance public expenditures, and the resulting higher inflation dampens productivity and growth ${ }^{10}$

Some recent studies on the finance-growth nexus posit that the relation between finance and growth is non-monotonic. This result is obtained by Cecchetti and Kharroubi (2012), who find that as bank credit to private sector exceeds $90 \%$ of GDP, finance becomes a drag on growth. Strikingly, a faster rate of growth of the financial sector may be detrimental to the growth of the economy because the financial sector competes for resources with the rest of the economy. ${ }^{11}$ Such a non-monotonic effect is observed also by Arcand et al. (2012), who utilize different types of datasets at the country level and industry level and find that the negative finance-growth relationship occurs once the ratio of private credit to GDP exceeds a threshold of about $110 \%$ for high-income countries. This result is consistent across different types of estimators, including simple cross-section OLS regression, semi-parametric estimations and system-GMM. ${ }^{12}$

\footnotetext{
${ }^{10}$ For similar considerations, see also King and Levine, 1993a; Greenwood and Smith, 1997; Levine, 1997; Levine, 2005).

${ }^{11}$ They also study this relationship by considering the share of financial sector employment to total employment and find that the turning point is $3.9 \%$ beyond which the GDP growth per worker becomes negative.

${ }^{12}$ On a related theme, Easterly et al. (2000), studying the link between the financial system and growth volatility, observe that greater credit or a deeper financial system is significantly associated with less volatility, but the relationship appears to be nonlinear. While developed financial systems offer opportunities for stabilization, they also may imply higher leverage of firms, which implies more risk and lower stability. The consumption and production smoothing possibilities provided by the existence of a deep financial system might reduce growth volatility, particularly when shocks are small, on average, but
} 
A more general finding, that the finance-growth relationship varies with the stage of development in a non-linear fashion, is put forward by Deidda and Fattouh (2002), who consider a cross-section of 119 (developed and developing) countries and apply threshold regressions to two groups of countries - high income and low income - and find that finance is a significant (insignificant) determinant of growth for high (low) income countries. Likewise, Rioja and Valev (2004a,b), working with panel data for the 1961-95 period for 74 (developed and developing) countries find that the effect is positive and significant in countries with high and intermediate income levels, but the effect is insignificant in lowincome countries. ${ }^{13}$ Threshold regressions with high- and low-income countries are performed also by Huang and Lin (2009), who consider a sample of 71 countries, but use a cross-section (where they consider an average from 1960 to 1995). The link between finance and growth via their IV threshold method is positive, but non-linear; however, in contrast to Deidda and Fattouh (2002) and Rioja and Valev (2004a,b), the effect is more pronounced for the low-income countries. An earlier paper by De Gregorio and Guidotti (1995) obtains a similar result of a weak relationship in high income countries: they attribute this to the fact that financial development in such countries occurs mainly outside of the banking system, while their proxy for financial development is bank credit to the private sector as a proportion of GDP.

As regards the mechanism through which financial development affects growth, Rioja and Valev (2004a,b) find that in high- (and also middle-) income countries, this happens mainly by enhancing productivity, while in low-income countries it occurs predominantly through capital accumulation: so a country has to reach a certain income level for financial development to contribute to productivity growth. On a similar theme, Calderon and Liu (2003) find that financial deepening propels growth through both capital accumulation and productivity growth, especially the latter. Rousseau and Wachtel (2002) identify the inflation channel as providing the link between financial development and growth, and find that growth is not affected when annual inflation exceeds $13 \%$.

Law and Singh (2014) explore whether finance promotes economic growth after a country's financial development exceeds a certain threshold level. Using dynamic panel threshold methods, they consider a panel of 87 (developed and developing) countries over the 1980-2010 period, averaged over 5 years periods. They find a threshold beyond which private sector credit is not beneficial. This threshold value is $88 \%$ of GDP, close to the Cecchetti and Kharroubi's (2012) value of $90 \%$. Threshold effects are also

up to a limit. As the financial system becomes larger relative to GDP, the increase in risk become relatively more important, and acts to reduce stability.

${ }^{13}$ Some earlier literature has also suggested that the effect of finance on growth is stronger for more developed countries: see for example, Demetriades and Hussein (1996), Odedokun (1996), and Xu (2000). 
considered by Law et al. (2013), but they attempt to identify the institutional quality thresholds that may affect the finance-growth relationship. Using data for 85 countries for the 1980-2008 period, and using both Hansen (2000)-type threshold regressions and Caner and Hansen (2004)-type IV threshold regressions, they find that institutions shape the finance-growth relationship: financial development promotes growth after institutions exceed a certain threshold level.

Owen and Temesvary (2014) contribute to the finance-growth literature by showing that the effect of bank finance on growth is heterogeneous across countries and across types of bank lending (domestic and foreign). Such heterogeneity is captured by grouping countries based on the conditional distribution of growth rates. Specifically, they find that country characteristics such as the extent of stock market development, the degree of rule of law, and even the development of the banking sector itself vary considerably across countries and affect the productivity of bank lending in encouraging growth. The issue about domestic and external sources of financing has been looked at, but with industry-level data, by Rajan and Zingales (1998), who provide new insights into the finance-growth relationship. Here, financial development reduces the costs of external finance to firms, so that industries that are more dependent on external financing (due to the initial project scale, cash-flow patterns, profit margins, etc.) ought to perform better in countries with more developed financial systems.

Beck et al. (2014) seek to disentangle the effects of the financial system by considering the effects of size (i.e., its value added as a proportion of GDP) and the degree of intermediation (i.e., the private credit-to-GDP ratio) on GDP per capita growth and growth volatility. Based on a sample of 77 countries for the period 1980-2007, they find using the OLS estimator that financial intermediation activities increase growth and reduce volatility in the long-run. ${ }^{14}$ Importantly, over the medium term, a large financial sector stimulates growth at the cost of higher volatility in high-income countries, while intermediation activities stabilize the economy, especially in low-income countries.

In a similar, but using a different methodology - the pooled mean group (PMG) estimator - Loayza and Ranciere (2006) distinguish between the short- and long-run effects of finance on growth. Employing annual data over the 1960-2000 period for 75 countries, the authors use a panel error correction model and estimate it by the PMG estimator. The novelty of this approach is that it allows for heterogeneity in parameters in growth regressions, apart from separating the short- and long-run effects of financial development. They find a significant and positive long-run relationship between

\footnotetext{
${ }^{14}$ As mentioned earlier, Easterly et al. (2000) find a non-linear effect of the financial system on growth volatility.
} 
financial development and economic growth, while the short-run impact is significant and negative. They suggest that the negative short-run effect may be a result of cross-country heterogeneity and higher volatility of business cycles. They, nevertheless, do not allow for the non-monotonic effect of financial deepening. Given that Loayza and Ranciere (2006) attempt to reconcile some of the remaining unresolved issues in the finance-growth nexus using a new and fairly novel methodology, we have adopted this in our own research.

Finally, addressing similar questions as Loayza and Ranciere (2006), but using a somewhat different approach, Rousseau and Wachtel (2011) show that the impact of financial deepening on growth is not as strong with more recent panel data (1990-2004) as for the period from 1960 to 1989. They posit that the rapid growth of credit and widespread liberalization in the nineties led to both inflationary pressures and a weakening of the banking system that ultimately triggered financial crises, which are responsible for "the disappearance of the finance effect". So, from a policy perspective, there appears to be a need for financial sector reform and regulation to accompany financial deepening. This finding is interesting and of topical relevance, and provides further motivation to the study we undertake in this paper.

As the preceding discussion makes clear, various empirical approaches have been used to explore the relationship between finance and growth. A summary of the type of data, econometric methods used, and the criticisms levelled against such methods may be in order here. Earlier research was based on cross-sectional data using standard OLS estimation methods, which confirmed the positive correlation between financial development and economic growth (see, for instance, Goldsmith, 1969; King and Levine, 1993a, 1993b; and Levine and Zervos, 1998). While their findings suggest that finance helps to predict long-term growth, a number of authors (Chuah and Thai, 2004; Khan and Senhadji, 2003; and Barro, 1991) argue that conclusions based on cross-sectional analysis are unreliable and have several econometric problems. First, the results are sensitive to the sample of countries chosen: it may be inappropriate to draw policy implications from cross-country studies that treat different economies as homogeneous entities. Second, they do not take advantage of time-series variation in the data. Finally, the issue of causality cannot be handled formally in cross-sectional studies (Khan and Senhadji, 2003). As Ahmed (1998) and Ericsson et al. (2001) point out, using instrumental variables does not solve the endogeneity problem when the data are averaged over long periods. Furthermore, using time-series data does not resolve these problems either: Christopoulos and Tsionas (2004) and Beck (2008) argue that high-frequency data are required to gain econometric power from the time series approach, which limits the analysis to just a few countries for which such data are available. 
In order to reduce the shortcomings of both cross-sectional and time series analysis, researchers have increasingly turned to panel data that enable them to combine time series and cross-sectional features and offer a variety of estimation approaches (for example Calderon and Liu, 2003; Christopoulos and Tsionas, 2004; Dawson, 2010). However, these studies apply either the traditional fixed or random effect methods, or the panel cointegration technique. The former averages the data per country to isolate the trend effects which hides the dynamic relationship between the variables of interests. The latter has the disadvantage that the evidence of long-term relationships can be obtained only when variables are integrated at the same level (Pesaran and Smith, 1995; Pesaran, 1997; and Pesaran and Shin, 1999). ${ }^{15}$ In our data and methodology sections that follow, we explain how we take into account the above points while deciding on the econometric exercises that we adopt in our paper.

\section{Data Description}

This study is based on panel data covering 23 upper and 29 lower-middle income countries, as classified by the World Bank (WB) in 2010, over the period 1980-2008, to examine the dynamic relationship between financial development and economic growth. ${ }^{16}$ Table 1 provides a list of the countries included in the sample.

\section{The dependent variable and the control variables}

The dependent variable is economic growth, measured as the growth rate of real GDP. As far as the control variables are concerned, we initially considered a broad set of control variables typically used in the growth literature: initial real GDP (to capture the tendency for growth rates to converge across countries over time); gross fixed capital formation (to account for investment in physical capital); population growth (as an indicator of the growth of the labor force); openness to trade (to capture the importance of international factors in influencing economic activity); government expenditure as a share of GDP (this captures the extent of public goods provided by the government, especially in education, health care and infrastructure, but it also reflects the distortionary effects of public spending and taxation), life expectancy (as a proxy for human capital ${ }^{17}$ ), and inflation (proxying for the stability

\footnotetext{
${ }^{15}$ This issue is discussed more extensively in the methodology section.

${ }^{16} \mathrm{We}$ have checked if there were any changes relative to the 2013 World Bank classification. We have found that Fiji moved to the lower income category. Ecuador, Jordan and Peru become upper middle income countries. However, it is noteworthy that when we re-estimated all the models with these changes, the results in terms of sign and significance level remain the same as in the main estimation in this paper. Therefore, we did not report these changes in our current version. A number of middle income countries were excluded from our sample due to lack of sufficient data.

${ }^{17}$ Our attempts to include education (specifically, secondary school enrolment) resulted in too many missing observations.
} 
of the macroeconomic and business environment). ${ }^{18}$ However, when including all variables in the regression, several turned out to be insignificant. We, therefore, proceeded to omit the insignificant explanatory variables one by one until we were left with a model that contained trade openness, government expenditure, population growth and fixed capital formation as control variables. The full results are available upon request.

\section{Measures of financial development}

The construction of the variables to capture financial development is a difficult task due to a number of reasons. Financial services are provided by a wide range of financial institutions and agents. Among them, banks and stock markets both play a major role. In order to capture a complete picture, we need to consider different aspects of financial development, for instance, whether the financial sectors of the studied countries are dominated by banks or the stock market or both. However, our prime objective is to investigate the long-run relationships. Therefore, we use bank-based financial proxies due to the unavailability of long-span time series data for the stock market for many of the countries. ${ }^{19}$

Most of the empirical literature on this topic uses monetary aggregates such as the M2 and/or M3 as a ratio of nominal GDP to capture the overall size and depth of the financial sector. However, some researchers such as Khan and Senhadji (2003) argue that M2/GDP might be a poor proxy for financial development in the case of countries with underdeveloped financial systems for two reasons. First, high level of monetization might be linked to financial underdevelopment. Second, M2 mostly captures the ability of the financial system to provide transaction services rather than its ability to link up surplus and deficit agents in the economy. Several papers including Beck et al (2000a); Favara (2003) and

\footnotetext{
${ }^{18} \mathrm{We}$ also included foreign direct investment (FDI) as a control in our regressions (we are grateful to a referee for suggesting this). FDI could increase growth by improving productivity, enabling technology transfers and introducing new processes and skills in the domestic market. However, whether FDI boosts growth could depend on the extent of development of domestic financial markets (Alfaro et al. (2004, 2010), Choong (2012)), or a sufficient level of human capital in the host country (Borensztein et al. (1998)). The results of the inclusion of FDI in our analysis did not essentially change the significance level or the sign of the financial development variable. We therefore do not report these results in the paper but can make them available upon request.

${ }^{19}$ We initially considered stock market indicators, such as market capitalization, turnover, and stock returns, as measures of financial development, along with bank-based indicators. However, due to missing data, we had to exclude these and utilize only the bank-based data. This mirrors the practice in much of the related literature on emerging economies which focuses on the banking sector and omits stock market development, either because of data unavailability, or because the banking sector is the dominant sector in these countries. For individual country examples, see Demetriades and Luintel, 1996, and Bhattacharya and Sivasubramanian, 2003, for the case of India;; Ang and McKibbin, 2007, for Malaysia; Ozturk, 2008, and Halicioglu, 2007, for Turkey. For middle income countries, see, for example, Hassan et al., 2011; Hauner, 2009. Given that Demirguc-Kunt and Levine (1999) find in a cross-section of 150 countries that the stock market tends to play a more important role in high income countries than in middle and lower income countries, we feel we should not lose much by not being able to include stock market variables.
} 
Deidda and Fattouh (2002) suggest to employ M3/GDP, which is a less liquid monetary aggregate, as a proxy for financial development. Therefore, in this paper we use the M3, as a proportion of GDP.

The M3/GDP captures the amount of liquid liabilities of the financial system, including the liabilities of banks, central banks and other financial intermediaries, that reflects financial deepening, which is in turn positively related with financial services (King and Levine, 1993a/b; Demetriades and Hussein, 1996; Favara, 2003). Nevertheless, Fry (1997) and Ang and McKibbin (2007) among others argue that monetary aggregates are not good proxies for financial development since they reflect the extent of transaction services provided by the financial system rather than the ability of the financial system to channel funds from depositors to investors. Therefore, credit to the private sector as a proportion of GDP is the third most widely used alternative measure of financial development (see Demetriades and Hussein, 1996; King and Levine, 1993a; Beck et al, 2000a; Favara, 2003; Liang and Teng, 2006; Arcand et al., 2011). The importance of this measure rests in the fact that it only accounts for credit granted to the private sector that enables the utilization of funds and their allocation to more efficient and productive activities. It also excludes credit issued by the central bank and thus is a more accurate measure of the savings that financial intermediaries channel to the private sector.

Some studies use the ratio of commercial bank assets divided by the sum of commercial bank and central bank assets (see, Ang and McKibbin, 2007; Campos and Kinoshita, 2008; Rioja and Valev, 2004a,b). This variable measures the relative importance of a specific type of financial institutions (commercial banks) in the financial system. Ang and McKibbin (2007) argue that the advantage of this measure is that commercial banks make more efficient use of funds than central banks by channeling savings to profitable investment opportunities.

Rather than use multiple closely related yet different variables, we construct an aggregate indicator of financial development to represent the overall development in the financial sector. The resulting variable combines the three aforementioned widely used indicators of financial development: the ratio of liquid liabilities (or M3) to nominal GDP, the ratio of commercial bank assets to the sum of commercial bank assets and central bank assets and the ratio of bank credit to the private sector to GDP. The source of these data is the 2008 version of World Bank's Financial Structure Dataset (Beck et al., 2000b). ${ }^{20}$ We follow Ang and McKibbin (2007), Gries et al. (2009), and Campos and Kinoshita (2010), among others, to combine these variables into a single indicator by using principal components analysis (PCA). We denote the resulting variable as FD. The advantages of doing this are two-fold.

\footnotetext{
${ }^{20}$ Available at http://econ.worldbank.org/staff/tbeck.
} 
First, the financial development variables are highly correlated amongst themselves. ${ }^{21}$ Using PCA serves to overcome the problem of multicollinearity. Second, studies attempting to investigate the link between financial development and growth have no uniform argument as to which proxies are most appropriate for capturing this linkage: they choose a number of different measures and subsequently come up with different results (see Chuah and Thai, 2004; Khan and Senhadji, 2003; King and Levine, 1993a; Savvides, 1995; among others). We believe that this new index of financial development is able to capture most of the information in the original data and is a better indicator than the individual variables.

Table 2 presents the results of the principal component analysis. The first component is the only one with an eigenvalue greater than 1 and it explains about $63 \%$ of the variation of the dependent variable. The second principal component explains another $28 \%$, and the last principal component accounts for only $9 \%$ of the variation. Hence, it is clear that the first principal component has the maximum explanatory power. We use it therefore as our financial development indicator (FD).

\section{Methodology and Model Specification}

In this section, we briefly review the general framework for analyzing panel data. First, we discuss, in terms of efficiency and consistency, the method employed in this study and compare it with other standard methods. Then, we rationalize the case for the use of a panel ARDL model based on the use of three alternative estimators: the mean group estimator (MG) of Pesaran and Smith (1995), the pooled mean group estimator (PMG) and the dynamic fixed effect (DFE) estimator developed by Pesaran et al. (1999).

\section{Static models}

The standard panel models, such as pooled OLS, fixed effects and random effects models have some serious shortcomings. For instance, pooled OLS is a highly restrictive model since it imposes a common intercept and slope coefficients for all cross-sections, and thus disregards individual heterogeneity. The fixed effects model, on the other hand, assumes that the estimator has common slopes and variance but country-specific intercepts. Both the cross-sectional and time effects can be

\footnotetext{
${ }^{21}$ We have repeated all empirical exercises presented in the paper with the individual measures of financial development. These results are very similar to those using the FD indicator, except with the ratio of commercial bank assets divided by the sum of commercial bank and central bank assets, which appears significant and positive in the long-run only in the case of middle income countries. Due to space concerns, we omit these results from the paper but they are available upon request.
} 
observed through the introduction of dummy variables, especially in two-way fixed effects models; however, this estimator faces severe problems due to the loss of degrees of freedom (Baltagi, 2008). Furthermore, the parameter estimates produced by the fixed effects model are biased when some regressors are endogenous and correlated with the error terms (Campos and Kinoshita, 2008). In contrast to the fixed effects model, the random effects model is relatively less problematic in terms of degrees of freedom by assuming common intercepts. Nevertheless, the random effects model has another limitation in that it considers the model to be time invariant. This implies that the error at any period is uncorrelated with the past, present and future, known as strict exogeneity (Arellano, 2003). In real life, this assumption is very often invalid. Additionally, as Loayza and Ranciere (2006) argue, static panel estimators do not take advantage of the panel dimension of the data by distinguishing between the short- and long-run relationships. Furthermore, conventional panel data models assume homogeneity of the coefficients of the lagged dependent variable (Holly and Raissi, 2009). This can lead to a serious bias when in fact the dynamics are heterogeneous across the cross-section units.

To conclude, the static panel approaches are unable to capture the dynamic nature of the data, which is a fundamental issue in the empirical growth literature. In addition, these estimators can only deal with the structural heterogeneity in the form of random or fixed effects, but impose homogeneity in the model's slope coefficients across countries even when there may be substantial variations between them.

\section{Dynamic panel model}

Roodman (2006) states that when the data feature a large numbers of countries $(\mathrm{N})$ relative to the time period (T), the GMM-difference estimator proposed by Arellano and Bond (1991) and the GMMsystem estimator by Arellano and Bover (1995) and Blundell and Bond (1998) work well. These two estimators are typically used to analyze micro panel datasets (Eberhardt, 2012). However, a wide range of recent literature has applied GMM techniques to macro panel data, including in the area of financial development and growth (e.g. Arcand, 2012). Roodman (2006) argues that in the small N and large T case, the GMM estimators are likely to produce spurious results for two reasons. First, small $\mathrm{N}$ might lead to unreliable autocorrelation test. ${ }^{22}$ Second, as the time span of the data gets larger, the number of instruments will get larger too. This affects the validity of the Sargan test of over-identification restriction and cause the rejection of the null hypothesis of the exogeneity of instruments. Hence, we have doubts about the reliability and consistency of the results obtained using GMM. Another point is

${ }^{22}$ The test of the (AR) by Arrelano-Bond is based on the assumption that there is no second-order serial correlation in the residuals of the first-difference equation. 
that GMM captures only the short-run dynamics and the stationarity of the variables tends to be ignored because these models are mostly restricted to short time series. Thus, it is not clear whether the estimated panel models represent a structural long-run equilibrium relationship or a spurious one (Christopoulos and Tsionas, 2004). More importantly, Kiviet (1995) argues that in GMM estimation the imposition of homogeneity assumptions on the slope coefficients of lagged dependent variables could lead to serious biases. ${ }^{23}$ These estimation procedures are likely to produce inconsistent and misleading long-run coefficients unless the slope coefficients are, indeed, identical (Pesaran and Smith, 1995; Pesaran, 1997; Pesaran and Shin, 1999).

Based on Pesaran et al. (1999), the dynamic heterogeneous panel regression can be incorporated into the error correction model using the autoregressive distributed lag $\operatorname{ARDL}(p, q)$ technique, where $p$ is the lag of the dependent variable, and $\mathrm{q}$ is the lag of the independent variables, and stated as follows (Loayza and Ranciere, 2006):

$$
\Delta G D P G_{i, t}=\sum_{j=1}^{p-1} \gamma_{\mathrm{j}}^{\mathrm{i}} \Delta G D P G_{i, t-j}+\sum_{\mathrm{j}=0}^{\mathrm{q}-1} \delta_{\mathrm{j}}^{\mathrm{i}} \Delta \mathrm{X}_{\mathrm{i}, t-j}+\varphi^{\mathrm{i}}\left[G D P G_{i, t-1}-\left\{\beta_{0}^{\mathrm{i}}+\beta_{1}^{\mathrm{i}} \mathrm{X}_{\mathrm{i}, \mathrm{t}-1}\right\}\right]+\epsilon_{\mathrm{it}}
$$

where GDPG is the GDP growth $\operatorname{rate}^{24}, \mathbf{X}$ is a set of independent variables including the financial development indicator, $\boldsymbol{\gamma}$ and $\boldsymbol{\delta}$ represent the short-run coefficients of lagged dependent and independent variables respectively, $\boldsymbol{\beta}$ are the long-run coefficients, and $\boldsymbol{\varphi}$ is the coefficient of speed of adjustment to the long-run equilibrium. The subscripts $\mathbf{i}$ and $\mathbf{t}$ represent country and time indexes, respectively. The term in the square brackets of equation (1) contains the long-run growth regression, which includes the long-run coefficients of $\mathrm{X}$ vectors, which is derived from the following equation.

$$
G D P G_{i, t}=\beta_{0}^{i}+\beta_{1}^{i} \mathrm{X}_{\mathrm{i}, t}+\mu_{i, t} \quad \text { where } \mu_{i, t} \sim I(0)
$$

Equation (1) can be estimated by three different estimators: the mean group (MG) model of Pesaran and Smith (1995), the pooled mean group (PMG) estimator developed by Pesaran et al. (1999), and the dynamic fixed effects (DFE) estimator. All three estimators consider the long-run equilibrium and the heterogeneity of the dynamic adjustment process (Demetriades and Law, 2006) and are computed by maximum likelihood.

Pesaran and Smith (1995), Pesaran (1997) and Pesaran and Shin (1999) present the autoregressive distributed lag (ARDL) model in error correction form as a relatively new cointegration test. However, here the emphasis is on the need to have consistent and efficient estimates of the parameters in a long-

\footnotetext{
${ }^{23}$ See Bond (2002) for further information about the use of GMM panel estimators in the empirical growth studies.

${ }^{24}$ We also tried the GDP per capita growth rate and the results were similar.
} 
run relationship. According to Johansen (1995) and Philipps and Hansen (1990), the long-run relationships exist only in the context of cointegration among variables with the same order of integration. Pesaran and Shin (1999) show that panel ARDL can be used even with variables with different orders of integration and irrespective of whether the variables under study are $\mathrm{I}(0)$ or $\mathrm{I}(1)$ or a mixture of the two. This is an important advantage of the ARDL model, as it makes testing for unit roots unnecessary. ${ }^{25}$ In addition, both the short-run and long-run effects can be estimated simultaneously from a data set with large cross-section and time dimensions. Finally, the ARDL model, especially PMG and MG, provides consistent coefficients despite the possible presence of endogeneity because it includes lags of dependent and independent variables (Pesaran et al, 1999). For further understanding of the key features of the three different estimators in the dynamic panel formwork, we present the assumptions relating to each estimator.

\section{Pooled Mean Group (PMG) model}

The main characteristic of PMG is that it allows the short-run coefficients, including the intercepts, the speed of adjustment to the long-run equilibrium values and error variances to be heterogeneous country by country, while the long-run slope coefficients are restricted to be homogeneous across countries. This is particularly useful when there are reasons to expect that the long-run equilibrium relationship between the variables is similar across countries or, at least, a sub-set of them. The short-run adjustment is allowed to be country-specific, due to the widely different impact of the vulnerability to financial crises and external shocks, stabilization policies, monetary policy and so on. However, there are several requirements for the validity, consistency and efficiency of this methodology. First, the existence of a long-run relationship among the variables of interest requires the coefficient on the error-correction term to be negative and not lower than -2. Second, an important assumption for the consistency of the ARDL model is that the resulting residual of the error-correction model be serially uncorrelated and the explanatory variables can be treated as exogenous. Third, the relative size of $\mathrm{T}$ and $\mathrm{N}$ is crucial, since when both of them are large this allows us to use the dynamic panel technique, which helps to avoid the bias in the average estimators and resolves the issue of heterogeneity. Eberhardt and Teal (2011) argue that the treatment of heterogeneity is central to understanding the growth process. Therefore, failing to fulfil these conditions will produce inconsistent estimation in PMG.

\footnotetext{
${ }^{25}$ Nevertheless, we test for the presence of unit roots to ensure that no series exceeds I(1) order of integration. We use the tests of Im, Pesaran and Shin (2003), Breitung (2000), Levin, Lin and Chu (2002) and Karavias and Tzavalis (2014). Asteriou and Monastiriotis (2004) indicate that when some variables are I(2), the estimation is not consistent. This is, however, not the case here. The results of these tests are available upon request.
} 


\section{Mean Group (MG) estimator}

The second technique (MG) introduced by Pesaran and Smith, (1995) calls for estimating separate regressions for each country and calculating the coefficients as unweighted means of the estimated coefficients for the individual countries. This does not impose any restrictions. It allows for all coefficients to vary and be heterogeneous in the long-run and short-run. However, the necessary condition for the consistency and validity of this approach is to have a sufficiently large time-series dimension of the data. The cross-country dimension should also be large (to include about 20 to 30 countries). Additionally, for small $\mathrm{N}$, the average estimators (MG) in this approach are quite sensitive to outliers and small model permutations (see Favara, 2003).

\section{Dynamic Fixed Effects (DFE) model}

Finally, the dynamic fixed effects estimator (DFE) is very similar to the PMG estimator and imposes restrictions on the slope coefficient and error variances to be equal across all countries in the long run. The DFE model further restricts the speed of adjustment coefficient and the short-run coefficient to be equal too. However, the model features country-specific intercepts. DFE has cluster option to estimate intra-group correlation with the standard error (Blackburne and Frank, 2007). Nevertheless, Baltagi et al (2000) point out that this model is subject to a simultaneous equation bias due to the endogeneity between the error term and the lagged dependent variable in case of small sample size.

\section{Model Selection}

We estimate equation (1) for the whole sample with PMG, MG and DFE. As we consider middleincome countries only, we expect this sample to be homogenous with respect to economic growth and financial development. However, in the short run, there is bound to be country-specific heterogeneity due to the effect of local laws and regulations. The PMG estimator offers more efficient estimates compared to the MG estimators under the assumption of long-run homogeneity. Moreover, the time span for this study is 28 years, and the MG estimator may lack degrees of freedom. Consequently, the PMG estimation is more relevant for this analysis. However, to choose among the MG, PMG and DFE methods, the Hausman test is used to test whether there is a significant difference between these estimators. The null of this test is that the difference between PMG and MG or PMG and DFE estimation is not significant. If the null is not rejected, the PMG estimator is recommended since it is efficient. The alternative is that there is a significant difference between PMG and MG or PMG and DFE and the null is rejected. If there are outliers the average estimator may have a large variance and in that case the Hausman test would have little power. The PMG will be used if the P-value is 
insignificant at the 5\% level. On the other hand, if it happens to have a significant P-value, then the use of a MG or DFE estimator is appropriate.

Another important issue is that ARDL lag structure should be determined by some consistent information criterion. ${ }^{26}$ Based on the Schwartz Bayesian criterion we impose the following lag structure $(1,1,1,1,1)$ for the GDP growth rate, fixed capital, government expenditure, population growth and financial development respectively. (The test results are available upon request). Finally, besides analyzing all middle-income countries together, we also consider whether there is a differential impact of financial development upon economic growth according to the income level by estimating separate models for upper and lower-middle income countries.

\section{Results and Discussion}

\section{A. PMG, MG and DFE: linear relationship}

In order to identify the impact of the variables of interest, error correction based on autoregressive distributed lag ARDL (p,q) model has been used, with focus on the exclusive feature of PMG model over the other error-correction based estimations, MG and DFE. Table 3 reports the results of PMG, MG and DFE estimation along with the Hausman $h$-test to measure the comparative efficiency and consistency among them. The results indicate that financial development (FD) has a negative but insignificant impact on economic growth in the long-run and no impact in the short-run according to the PMG estimator, whereas the MG estimator suggests a positive and insignificant coefficient in the long-run but negative and significant coefficient in the short-run. The DFE model, in turn, suggests a significant and negative impact of FD on growth in the long- as well as short-run. The validity of the long-run homogeneity restriction across countries, and hence the efficiency of the PMG estimator over the other estimators, is examined by the Hausman test. As expected, the Hausman test accepts the null hypothesis of the homogeneity restriction on the regressors in the long-run, which indicates that PMG is a more efficient estimator than MG. Similarly, comparing the result of DFE and PMG, the Hausman test again clearly favors the PMG specification over DFE.

Next, we examine to what extent the above finding varies with the income level by re-estimating the models for the sub-samples, the upper-middle income countries (UMIC) and lower-middle income

\footnotetext{
${ }^{26}$ Lag structure might also be imposed according to the data limitation. When the time dimension is not long enough to overextend the lags, one can impose a common lag structure across countries (see, Pesaran et al, 1999; Loayza and Ranciere, 2006; Demetriades and Law, 2006).
} 
countries (LMIC). The results for the UMIC are reported in Table 4. The long-run coefficient of FD this time appears highly significant with the negative sign under PMG and DFE approaches, but insignificant under MG . As regards the short-run FD coefficients, they appear negative and statistically significant with all three estimators. Again, the Hausman test confirms that the PMG estimator is the efficient estimator compared to MG and DFE in the case of UMIC.In contrast, when LMIC are considered as shown in Table5, all the three approaches find a statistically insignificant impact of FD on long- and short-run growth.

To summarize, these results undermine the notion that financial development has a positive and significant long-run impact on economic growth in the MIC as a whole or in the LMIC. Moreover, they suggest that financial development has a negative and significant impact on long-run growth in the UMIC. Furthermore, financial development does not contribute to economic growth in the short-run, with the three models, PMG, MG and DFE, yielding similar results. ${ }^{27}$ Finally, the results from the Hausman test for the three samples; MIC and the sub-samples, UMIC and LMIC, suggest that the regressors have homogeneous long-run and heterogeneous short-run effects on growth.

Our findings contradict the common assumption that financial development plays an essential role in promoting economic growth. Nevertheless, they are in line with Ang and McKibbin (2007), who find that the return from financial development depends on the mobilization of savings and allocation of funds to productive investment projects. Due to frictions in the market in the form of high transaction costs and improper allocation of resources, the interaction between savings and investment and its link with economic growth is not strong in developing countries. Our findings of an adverse effect of financial development on economic growth in UMIC are consistent also with Arcand et al. (2012), Easterly et al. (2000), and Deidda and Fattouh (2002). These studies find either a negative or an insignificant impact of financial development on economic growth, in different cross-county samples. Furthermore, our results tally with Sundarajan and Balino (1991) and Gavin and Hausman (1998), who found a weak and sometimes negative impact of financial development on economic growth. They attribute their finding to the expansion in credit along with a lack of regulatory control and monitoring

\footnotetext{
${ }^{27}$ As a robustness check, we have repeated all empirical exercises presented in the paper with the individual measures of financial development: the ratio of liquid liabilities (M3) to GDP, private credit/GDP and bank asset/GDP. These results are similar to those using the FD indicator, with the exception of those with the the ratio of commercial bank assets to the sum of commercial bank and central bank assets, which appears significant and positive in the long-run only in the case of middle income countries. Given that the most commonly used measure of financial development, monetary aggregates and credit to private sector, yield the same results as our FD measure, we have omitted them from the text but they are available upon request. As another robustness check, we changed the lag structure to $(1,0,0,0,0)$ according to the data limitation (Loayza and Ranciere (2006)) but the results remain the same for FD variable that is either negative and significant or has no impact on growth. Therefore, we omit them in this version of the paper but make them available upon request.
} 
from the bankers. This may result in an inappropriate selection of projects, which could show up as an adverse impact of financial development on economic growth.

\section{B. Non-monotonic relationship}

As far as the econometrics is concerned, there is no single correct approach to modelling nonlinearity. Polynomials (such as adding squares) and threshold models are both used. They take different approximations: polynomials are smooth functions while threshold models may entail sharp discrete shifts. To investigate the potential non-monotonicity in the linkage between financial development and economic growth, this study applies both techniques.

\section{B.1. Quadratic polynomial of financial development}

Arcand et al. (2012), Easterly et al. (2000), and Deidda and Fattouh (2002) find a non-monotonic association between FD and economic growth. Specifically, Deidda and Fattouh (2002), focusing on high and low income countries, conclude that the relationship between financial development and economic growth is non-linear. Therefore, we check for the existence of a non-monotonic relationship as well. To accomplish the task, we first include a quadratic term of FD in the panel ARDL model, the results of which are shown in Tables $-6,-7$ and 8. Interestingly, Table 6 reveals that FD has a positive and significant coefficient, while $\mathrm{FD}^{2}$ has a negative and significant coefficient under the PMG estimation in the whole sample (MIC). Hausman test results confirm again that PMG is a better estimator than MG and DFE. This result supports the "Too Much Finance" hypothesis put forward by Arcand et al. (2012). It confirms that the marginal effect of financial development in the long-run is positive up to a certain threshold point, and negative after the threshold. ${ }^{28}$ For a number of countries in our sample, the size of the financial sector may be too large with respect to the socially optimal level. Hence, increasing FD can have a negative marginal effect on GDP growth. Note that these findings are almost the same for the whole sample, UMIC and LMIC. ${ }^{29}$

\footnotetext{
${ }^{28}$ Specifically, the turning point of the long-run relationship is attained at a value of FD equal to 1.03. Given the distribution of FD, this implies that the relationship between financial development and growth is positive for nearly $80 \%$ of observations included in our sample. Note that the short-run effect is not significantly different from zero, which is why we only compute the turning point for the long-run coefficients.

${ }^{29}$ Loayza and Ranciere (2006), who use a similar methodology as ours, do not consider the possibility that the effect of financial development might be non-monotonic. As a robustness check, we replicate their analytical framework with our data: to do this, we add the initial GDP per capita and inflation terms and omitt population growth; we use our composite FD measure rather than the ratio of credit to the private sector to GDP used by Loayza and Ranciere. Reassuringly, we obtain a similar result: FD appears to have a significantly positive effect on growth when entered linearly. This indicates that the differences between our results and those of Loayza and Ranciere are not due to the choice of sample. Importantly, when we enter FD as a quadratic polynomial, both the linear and quadratic terms are significant and the effect of FD on growth is inverted U-shaped, as in the baseline results reported above. Hence, the relationship between financial development and growth remains inverted U-shaped even when we replicate Loayza and Ranciere's result while allowing
} 


\section{Sufficient Condition for a Quadratic Relationship:}

Lind and Mehlum (2010) point out that the conventional econometric model is not suitable for testing the composite null hypothesis that at the left side of the interval the relationship is decreasing, and at the right side of the interval it is increasing, or vice-versa. Moreover, Arcand et al. (2012) argue that if the model does not allow for non-monotonocity, it may lead to a downward bias in the estimated effect of financial development on economic growth. Therefore, to confirm our finding of an inverted $\mathrm{U}$ shaped relationship, we conduct the $U$ test of Lind and Mehlum (2010). To accomplish this, we estimate the following model:

$$
g d p g_{i}=a F D_{i}+b F D_{i}^{2}+Z_{i} C+\varepsilon_{i}
$$

Then test the joint hypothesis:

$$
H_{0}:\left(a+b 2 F D_{\min } \leq 0\right) \cup\left(a+b 2 F D_{\max } \geq 0\right)
$$

against the alternative hypothesis:

$$
H_{1}:\left(a+b 2 F D_{\min }>0\right) \cup\left(a+b 2 F D_{\max }<0\right)
$$

where $\mathrm{FD}_{\min }$ and $\mathrm{FD}_{\max }$ represent the minimum and maximum values of financial development, respectively. If the null hypothesis is rejected, this confirms the existence of an inverted $\mathrm{U}$ shape.

The test results in Table 9 show that the lower bound slope of FD is positive (0.74) while the upper bound slope of FD is negative (-1.04). Both are statistically significant which means that the null hypothesis of no inverted U-shape is rejected. We also conduct this test for the two sub-samples. The lower bound slope of FD is positive (0.82) while the upper bound slope is negative (-0.87) for the UMIC subsample. Both are statistically significant at $10 \%$ which again means that the null hypothesis of no inverted U-shape is rejected for the upper middle income countries. Similarly, the U-Test also indicates that inverted $\mathrm{U}$ shape exits in the lower middle-income countries as the lower bound of FD is positive $(0.92)$ while the upper bound slope is negative (-1.21). Both are highly significant at $1 \%$ (these results are also included in Table 9). The SLM test in the bottom panel of Table 9 for MIC, UMIC and LMIC shows that the null hypothesis is rejected, which indicates that our results are consistent with the presence of an inverted $U$-shaped relationship between financial development and economic

for non-monotonicity. These results are available upon request. We are grateful to an anonymous referee for suggesting this exercise. 
growth. ${ }^{30}$ As regards the control variables, all the models used in this paper found more or less similar results. Trade has a positive and significant impact on economic growth in the long-run, in the whole set of middle income countries (and also among upper-middle and lower-middle income countries). This result is consistent with several theoretical predictions and empirical findings in the literature: see, for example, Dollar (1992), Ben-David (1993), Sachs and Warner (1995), Harrison (1996), Edwards (1998), Frankel and Romer (1999), Easterly and Levine (2001), Irwin and Tervio (2002), Dollar and Kraay (2003), etc., and is a reflection of the favorable effects of policies encouraging trade liberalization and globalization pursued by many of these countries, as well as issues linking trade with technology transfers, institutional quality and geographical factors. In the short-run, trade exhibits a negative but insignificant impact on growth for all MIC and UMIC, except in one case as shown in Table 5, where the trade coefficient appears to be negative and significant for the LMIC. This finding may appear to be somewhat unusual, but some of the literature points to the possibility of trade hindering growth if there is specialization in the 'wrong' sector (which is an old argument in favor of trade protectionism, see Ethier, 1982).

In line with much of the literature, the long-run impact of fixed capital formation was found to be positive and significant for the lower-middle income countries, but in the sample including all middle income countries, this effect was positive but insignificant. However, somewhat surprisingly, Tables 4 and 7 suggest that fixed capital formation adversely affects economic growth for upper-middle income countries in the long-run. Neoclassical growth theory asserts that long-run growth cannot be sustained through capital deepening alone (Solow, 1957), as diminishing returns to physical capital set in, and what is required to overcome this is the complementary effect of human capital and/or public capital in production. ${ }^{31}$ One could point to the ineffectiveness of these complementary inputs (the issue we turn to next) as a causal factor behind this result. The negative impact of physical capital in the long-run could also be due to the absence of proper market incentives in these countries that renders physical capital relatively unproductive.

In all the models, government expenditure negatively and significantly impacts on economic growth in both long-run and short-run. This can happen because of an increase in government consumption expenditure, which usually has distortionary effects, when accompanied by an increase in the present

\footnotetext{
${ }^{30}$ Further robustness checks have been carried out for detecting both outliers and leverage points. This resulted in removing Tonga, Vanuatu, Dominica, India and Indonesia from the analysis. This had little influence on the estimators, nevertheless. These results are available upon request.

${ }^{31}$ See, for instance, Mankiw et al. (1992) and Futagami et al. (1993) on the importance of human and public capital, respectively, in promoting growth.
} 
and/or future tax burden on citizens, and which leads to a reduction in private spending and investment (Barro, 1974, 1991). Even when a sizeable proportion of public spending in an economy is attributed to government investment, our results may be vindicated when a shift towards an a priori more productive category of spending may not raise the growth rate if its initial share is too high (Devarajan et al., 1996), or if optimizing governments misperceive the productivities of the different types of public goods and allocate their expenditures out of line with their productivities (Ghosh and Gregoriou, 2008).

Moreover, we obtain an insignificant impact of population growth on economic growth in the long-run as well as short-run in most cases. The signs of the coefficient of population growth in both short- and long-run are mixed, which implies that the impact of population growth on economic growth remains inconclusive, in contrast to much of the empirical research that finds a negative effect of population growth on economic growth. This happens typically because with higher population growth, the available capital must be spread more thinly over the population of workers (see Mankiw et al., 1992). However, there are others like Simon (1996) who argues that population growth can put pressure on resources and raise prices, but this process provides incentives for innovation which turn out to be so successful that the price changes are reversed and income grows with time. So, the impact of population growth could well be mixed.

\section{B.2. Robustness check using Panel Threshold model ${ }^{32}$}

As another approach to examine nonlinearity in the finance-growth nexus, we apply a newly developed panel threshold estimator. In a seminal work, Hansen (1999) proposed a panel threshold estimator that is only suitable for static and balanced panels. However, some macroeconomic variables such as GDP growth are highly persistent, meaning that a dynamic panel framework is more appropriate. To consider nonlinearity in dynamic panel data, Bick (2010) and Kremer et al. (2013) proposed a dynamic panel threshold estimator which is an extension of the threshold models by Hansen (1999), Hansen (2000), and Caner and Hansen (2004). This estimator allows us to investigate the potential existence of a discrete shift in a dynamic framework. Accordingly, the structural equation of interest with one potential threshold, $\gamma$, is given by

$$
G D P G_{i t}=\mu_{i}+\beta_{1} F D_{i t} I\left(F D_{i t} \leq \gamma\right)+\delta_{1} I\left(F D_{i t} \leq \gamma\right)+\beta_{2} F D_{i t} I\left(F D_{i t}>\gamma\right)+\emptyset z_{i t}+\varepsilon_{i t}
$$

\footnotetext{
${ }^{32} \mathrm{We}$ are grateful to an anonymous referee for proposing this extension.
} 
where subscript $i=1, \ldots, N$ indexes the country and $t=1, \ldots, T$ represents the time; $\mu_{i}$ stands for the country specific fixed effects; $I($.$) is an indicator function and depending on whether the threshold$ variable is larger or smaller than $\gamma$, it divides the observations into two regimes distinguished by differing regression slopes, $\beta_{1}$ and $\beta_{2} ; \delta_{1}$ is the regime intercept which is the same for all individuals; and $z_{i t}$ is an m-dimensional vector of explanatory variables, including the GDP at $t-1$ and the remaining control variables entered contemporaneously.

The dynamic panel threshold estimation results of equation (6) are presented in Table 10. In particular, three estimations are reported: In the first column, all MIC are considered, while the second and the third columns represent estimation results for UMIC and LMIC, respectively. The estimated threshold values of the FD indicator are around 0.92 for MIC and UMIC while it decreases to 0.433 for LMIC, suggesting that the turning point is lower for the LMIC. Among all MIC in our sample, 28 countries, or $54 \%$ of countries, exceed the threshold value of 0.915 . The most striking feature of our results is that the estimated coefficients on FD have different signs above and below the threshold level in all equations. More specifically, below the threshold regime, the estimated coefficient of FD is positive and significant in all equations with the exception of LMIC. However, the FD coefficients turn out to be negative and statistically significant above the threshold regime. This indicates that an increase in finance below the threshold value enhances growth whereas excessive FD beyond the threshold value undermines economic growth. Given the distribution of the FD indicator, this implies that the relationship between financial development and economic growth is positive for nearly $78 \%$ of observations included in our sample. ${ }^{33}$ Our results again lend support to the view that excessive finance harms the economy and are consistent with the findings of previous empirical studies (see e.g., Arcand et al.,2012; Rousseau and Wachtel, 2011; Law and Singh, 2014, among others). As for control variables, almost all variables used in the threshold model have coefficients similar to those we obtained in our previous finding with the exception of fixed capital formation and population. We do not replicate the discussion of the control variables for brevity. Briefly, fixed capital formation is found to be statistically highly significant for all MIC, UMIC and LMIC. As regards the population growth variable, it appears to be statistically insignificant for all middle income countries and for lower middle income countries, but positive and significant for upper middle income countries. Overall, considering that all control variables are plausibly signed, our empirical results from the dynamic panel threshold estimation confirm the existence of an inverted $U$ shape in the financial-growth relationship.

\footnotetext{
${ }^{33}$ This is very close to the turning point we obtained from inserting the square of FD. See footnote 28.
} 


\section{Concluding Remarks}

Financial development and economic growth have traditionally been strange bedfellows. Most studies conclude that on the whole, financial development plays a significant role in fostering growth. However, some recent studies find that financial deepening adversely affects growth. In this paper, we apply advanced econometric techniques to assess the impact of FD on growth. These include the errorcorrection based autoregressive distributed lag ARDL (p,q) model, which offers three different tests: namely, mean group (MG) presented by Pesaran and Smith (1995), pooled mean group (PMG) developed by Pesaran et al. (1999), and dynamic fixed effect (DFE) estimators. In doing so, we specifically allow for a non-linear relationship between financial development and economic growth. The results obtained when imposing a linear relationship suggest that financial development and economic growth are negatively associated in the long-run in the sample of all middle income countries. This finding is partially in line with Loayza and Ranciere (2006) who found that FD negatively influences economic growth in the short-run, but not in the long-run.

In an effort to go beyond Loayza and Ranciere (2006), we explore the possible non-monotonic impact of FD on growth by applying two different methodologies: we introduce a quadratic polynomial of financial development, and estimate a threshold model. Our findings demonstrate that financial development and economic growth are not linearly related, similar to the findings of Arcand et al. (2012). Specifically, we find evidence of an inverted U-shaped relationship. We confirm this using the Lind and Mehlum's (2007) U-test to obtain sufficient conditions for the existence of an inverted U relationship. These results suggest that more finance might not always be better in the case of the MIC. Moreover, our empirical results from the dynamic panel threshold estimation confirm the existence of an inverted $U$ shape in the finance-growth nexus.

We also conclude that the impact of financial development varies across the countries due to the heterogeneous nature of economic structures, institutional quality, financial markets, and so on. However, we believe that our results are of potential importance to policymakers in terms of optimizing the financial deepening that needs to be undertaken to ensure that the maximum possible gain for the economy can be achieved through the banking sector. Specifically, an intermediate level of financial development should be associated with optimal growth performance. Encouraging financial development for its own sake, therefore, may be counter-productive. Rather, policymakers should seek to strengthen the appropriate type and quality of finance rather than expanding the financial sector per $s e$. They could then focus on other growth-enhancing strategies if the appropriate finance threshold has 
been achieved. This resonates with the argument put forward, among others, by Cetorelli and Peretto (2012). They point out that the relationship between financial development and accumulation of physical capital is ambiguous: more bank competition translates into more credit availability for firms, but at the same time banks provide fewer additional services to the firms, resulting in greater probability of the investment failing (see also Bezemer et al., 2014; and Law and Singh, 2014). Further research should shed more light on this, including the factors that underlie the relationship between financial development and economic growth (or investment). Possible underlying factors could include the level of economic development and/or the quality of the institutional environment. 


\section{Tables}

Table 1: Sample of Countries

\begin{tabular}{ll}
\hline Upper Middle Income $^{\mathbf{3 4}} \mathbf{( 2 3 )}$ & Lower Middle Income $\mathbf{~}^{\mathbf{3 5}} \mathbf{( 2 9 )}$ \\
\hline Algeria & Belize \\
Argentina & Bolivia \\
Brazil & Cameroon \\
Chile & Cape Verde \\
Colombia & Congo, Rep. \\
Costa Rica & Cote d'Ivoire \\
Dominica & Ecuador \\
El Salvador & Egypt, Arab Rep. \\
Fiji & El Salvador \\
Gabon & Guatemala \\
Grenada & Guyana \\
Iran, Islamic Rep. & Honduras \\
Jamaica & India \\
Malaysia & Indonesia \\
Mauritius & Jordan \\
Mexico & Sri Lanka \\
Panama & Syrian Arab Republic \\
Seychelles & Swaziland \\
South Africa & Papua New Guinea \\
Suriname & Paraguay \\
Turkey & Peru \\
Uruguay & Philippines \\
Venezuela, RB & Senegal \\
& Thailand \\
& Tonga \\
& Tunisia \\
& Vanuatu \\
& Morocco \\
& Pakistan \\
\hline
\end{tabular}

Table 2: Principal component analysis for financial depth index ${ }^{36}$ :

\begin{tabular}{ccccc}
\hline Component & Eigenvalue & Difference & Proportion & Cumulative \\
\hline Comp1 & 1.88 & 1.02 & 0.63 & 0.63 \\
Comp2 & 0.85 & 0.58 & 0.28 & 0.91 \\
Comp3 & 0.26 &. & 0.09 & 1.00 \\
\hline
\end{tabular}

\footnotetext{
${ }^{34}$ The World Bank classification of economies is based on estimates of gross national income (GNI) per capita in 2010. Upper middle income countries are ones for which GNI per capita for the previous year is $\$ 4,086$ to $\$ 12,615$.

${ }_{36}^{35}$ Lower middle income countries are ones for which GNI per capita for the previous year is $\$ 1,036$ to $\$ 4,086$.
} 
Table 3: All Middle Income Countries

\begin{tabular}{|c|c|c|c|c|c|c|}
\hline \multirow{2}{*}{ Variable } & \multicolumn{2}{|c|}{ Pooled Mean Group } & \multicolumn{2}{|c|}{ Mean Group } & \multicolumn{2}{|c|}{ Dynamic Fixed Effect } \\
\hline & Coef. & Std. Error & Coef. & Std. Error & Coef. & Std. Error \\
\hline \multicolumn{7}{|l|}{ Long-Run Coefficients } \\
\hline Trade & $2.799 * * *$ & $(0.436)$ & $6.063 * * *$ & $(2.209)$ & $4.098 * * *$ & $(0.673)$ \\
\hline Fixed Capital & 0.0605 & $(0.474)$ & 0.0306 & $(1.271)$ & 0.454 & $(0.741)$ \\
\hline Government Expenditure & $-2.151 * * *$ & $(0.482)$ & $-6.17 * * *$ & (2.198) & $-2.861 * * *$ & $(0.704)$ \\
\hline Population Growth & -0.111 & $(0.182)$ & 0.188 & $(1.332)$ & $0.624 * *$ & $(0.283)$ \\
\hline Financial Development & -0.145 & $(0.115)$ & 0.0122 & $(0.635)$ & $-0.498 * * *$ & $(0.186)$ \\
\hline Error correction Coefficient & $-0.891 * * *$ & $(0.043)$ & $-1.128 * * *$ & $(0.039)$ & $-0.794 * * *$ & $(0.025)$ \\
\hline$\Delta$ Trade & -1.61 & $(1.693)$ & 0.647 & $(2.075)$ & -0.794 & $(0.966)$ \\
\hline$\Delta$ Fixed Capital & $11.59 * * *$ & $(1.516)$ & $9.906 * * *$ & $(1.567)$ & $8.077 * * *$ & $(0.797)$ \\
\hline$\Delta$ Government Expenditure & $-10.97 * * *$ & $(1.963)$ & $-11.67 * * *$ & $(2.238)$ & $-4.801 * * *$ & $(1.040)$ \\
\hline$\Delta$ Population Growth & 4.144 & $(4.881)$ & $12.87 *$ & (7.289) & -0.239 & $(0.297)$ \\
\hline$\Delta$ Financial Development & -0.847 & $(0.542)$ & $-1.474 * *$ & $(0.647)$ & $-1.032 * * *$ & $(0.363)$ \\
\hline Intercept & $-1.766^{* * *}$ & $(0.296)$ & -2.229 & $(11.260)$ & $-6.736 * *$ & $(3.040)$ \\
\hline Country & 52 & & 52 & & 52 & \\
\hline Observation & 1,454 & & 1,454 & & 1,454 & \\
\hline Hausman Test & & & $3.92^{\mathrm{a}}$ & & $4.18^{b}$ & \\
\hline p-value & & & 0.560 & & 0.523 & \\
\hline
\end{tabular}

Notes:*, $* *$, and $* * *$ indicate significance at $10 \%, * *$ at $5 \%$ and $* * *$ at $1 \%$. Estimations are done by using (xtpmg) routine in Stata. Pooled mean group, mean group, and dynamic fixed effects, all controlling for country and time effects. While the first panel (LR) shows long-run effects. The second panel reports both short-run effects (SR) and the speed of adjustment (ec).Hausman test is indicating that PMG is consistent and efficient estimation than MG and DFE estimation. The lag structure is ARDL $(1,1,1,1,1,1)$ and the order of variables is: GDP Growth, Trade, Fixed Capital, Government Expenditure, Population and Financial Development. All the middle income countries, annual data 1980-2008. Source: Authors' estimations.

${ }^{\text {a }}$ PMG is more efficient estimation than MG under null hypothesis.

${ }^{\mathrm{b}} \mathrm{PMG}$ is more efficient estimation than DFE under null hypothesis. 
Table 4: Upper Middle Income Countries

Pooled Mean Group Mean Group Dynamic Fixed Effect

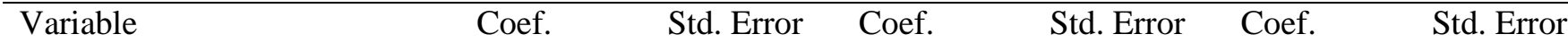

Long-Run Coefficients

Trade

Fixed Capital

Government Expen.

Population Growth

Financial Development

Error correction Coefficient

$\Delta$ Trade

$\Delta$ Fixed Capital

$\Delta$ Government Expenditure

$\Delta$ Population Growth

$\Delta$ Financial Development

Intercept

Country

Observation

Hausman Test

$\mathrm{p}$-value
$2.481 * * *$

$-1.474 * *$

$-3.326 * * *$

$-0.352^{*}$

$-0.327 * *$

(0.163)

$-0.0471$

$(0.477)$

$-0.72 * * *$

$-0.938 * * *$

(0.063)

$-1.171 * * *$

$(0.058)$

$-0.85^{* * *}$

1.379

(3.065)

$-1.083$

$(2.698)$

$10.52 * * *$

$-11.12 * * *$

(2.376)

$-14.27 * * *$

$(2.654)$

$-4.64 * * *$

7.873

(12.880)

12.3

(14.260)

$-0.438$

$-1.602 *$

(0.945)

$-2.081 *$

(1.114)

$-1.50 * * *$

16.64

(17.850)

$-2.069$

23

23

Note: $*, * *$ and $* * *$ indicate significance at $10 \%, * *$ at $5 \%$ and $* * *$ at $1 \%$. Estimations are done by using (xtpmg) routine in Stata. Pooled mean group, mean group, and dynamic fixed effects, all controlling for country and time effects. While the first panel (LR) shows long-run effects. The second panel reports both short-run effects (SR) and the speed of adjustment (ec). Hausman test is indicating that PMG is consistent and efficient estimation than MG and DFE estimation. The lag structure is ARDL $(1,1,1,1,1,1)$ and the order of variables is: GDP Growth, Trade, Fixed Capital, Government Expenditure, Population and, Financial Development. Upper Middle Income, annual data 1980-2008.

${ }^{a} \mathrm{PMG}$ is more efficient estimation than MG under null hypothesis.

${ }^{\mathrm{b}} \mathrm{PMG}$ is more efficient estimation than DFE under null hypothesis. 
Table 5: Lower Middle Income Countries

Pooled Mean Group $\quad$ Mean Group Dynamic Fixed Effect

\begin{tabular}{|c|c|c|c|c|c|c|}
\hline Variable & Coef. & Std. Error & Coef. & Std. Error & Coef. & Std. Error \\
\hline \multicolumn{7}{|l|}{ Long-Run Coefficients } \\
\hline Trade & $2.924 * * *$ & $(0.545)$ & $6.842 *$ & (3.617) & $3.729 * * *$ & $(0.926)$ \\
\hline Fixed Capital & $1.265^{* *} *$ & $(0.605)$ & 1.386 & $(1.552)$ & $1.840^{*}$ & $(0.993)$ \\
\hline Government Expen. & $-1.892 * * *$ & $(0.670)$ & -2.258 & $(2.548)$ & $-3.32 * * *$ & $(1.032)$ \\
\hline Population Growth & 0.128 & $(0.247)$ & 0.724 & $(1.767)$ & $0.905 * *$ & $(0.382)$ \\
\hline Financial Development & 0.0995 & $(0.168)$ & 0.0592 & $(1.085)$ & -0.164 & $(0.278)$ \\
\hline Error correction Coefficient & $-0.851 * * *$ & $(0.058)$ & $-1.00 * * *$ & $(0.053)$ & $-0.74 * * *$ & $(0.034)$ \\
\hline$\Delta$ Trade & $-0.851 * * *$ & $(0.058)$ & $-1.09 * * *$ & $(0.053)$ & $-0.74 * * *$ & $(0.034)$ \\
\hline$\Delta$ Fixed Capital & -2.442 & $(2.084)$ & 0.0667 & $(2.860)$ & -0.361 & $(1.290)$ \\
\hline$\Delta$ Government Expen. & $8.528 * * *$ & $(1.776)$ & $6.93 * * *$ & $(1.665)$ & $4.865 * * *$ & (1.127) \\
\hline$\Delta$ Population Growth & $-10.71 * * *$ & $(3.203)$ & $-9.60 * * *$ & (3.408) & $-4.959 * * *$ & (1.391) \\
\hline$\Delta$ Financial Development & 3.035 & $(3.405)$ & $13.33^{*}$ & $(6.847)$ & -0.236 & $(0.358)$ \\
\hline Intercept & $-6.167 * * *$ & $(0.504)$ & -17.19 & $(14.040)$ & $-7.963 * *$ & (3.994) \\
\hline Country & 29 & & 29 & & 29 & \\
\hline Observation & 810 & & 810 & & 810 & \\
\hline Hausman Test & & & $0.88^{\mathrm{a}}$ & & $2.54^{\mathrm{b}}$ & \\
\hline $\mathrm{p}$-value & & & 0.971 & & 0.770 & \\
\hline
\end{tabular}

Note: $*, * *$, and $* * *$ indicate significance at $10 \%, * *$ at $5 \%$ and $* * *$ at $1 \%$. Estimations are done by using (xtpmg) routine in Stata. Pooled mean group, mean group, and dynamic fixed effects, all controlling for country and time effects. While the first panel (LR) shows long-run effects. The second panel reports both short-run effects (SR) and the speed of adjustment (ec). Hausman test is indicating that PMG is consistent and efficient estimation than MG and DFE estimation. The lag structure is ARDL $(1,1,1,1,1,1)$ and the order of variables is: GDP Growth, Trade, Fixed Capital, Government Expenditure, Population and Financial Development. Lower Middle Income countries, annual data 1980-2008.

${ }^{a} \mathrm{PMG}$ is more efficient estimation than MG under null hypothesis.

${ }^{\mathrm{b}} \mathrm{PMG}$ is more efficient estimation than DFE under null hypothesis. 
Table 6: All Middle Income Countries with Non-linear Effect of FD

Model: GDPG $=f$ (Trade, Fixed Capital, Government, Population Growth, Financial Development, Financial development Square).

Pooled Mean Group $\quad$ Mean Group $\quad$ Dynamic Fixed Effect

\begin{tabular}{|c|c|c|c|c|c|c|}
\hline Variable & Coef. & Std. Error & Coef. & Std. Error & Coef. & Std. Error \\
\hline \multicolumn{7}{|l|}{ Long-Run Coefficients } \\
\hline Trade & $2.923 * * *$ & $(0.460)$ & $5.528 * *$ & $(2.468)$ & $3.954 * * *$ & $(0.669)$ \\
\hline Fixed Capital & 0.22 & $(0.468)$ & 1.007 & $(1.393)$ & 0.553 & $(0.741)$ \\
\hline Government Expen. & $-2.31 * * *$ & $(0.511)$ & $-6.60 * * *$ & $(2.360)$ & $-3.29 * * *$ & $(0.712)$ \\
\hline Population Growth & 0.0268 & $(0.187)$ & 0.0916 & $(1.469)$ & $0.528 *$ & $(0.281)$ \\
\hline Financial Development & $0.246^{* *}$ & $(0.125)$ & -2.97 & $(1.817)$ & -0.29 & $(0.197)$ \\
\hline Financial Development SQ & $-0.12 * * *$ & $(0.039)$ & -0.938 & $(0.986)$ & $-0.15^{* * *}$ & $(0.061)$ \\
\hline Error correction Coefficient & $-0.89 * * *$ & $(0.044)$ & $-1.17 * * *$ & $(0.039)$ & $-0.79 * * *$ & $(0.025)$ \\
\hline$\Delta$ Trade & -1.645 & $(1.687)$ & 0.754 & $(2.101)$ & -0.856 & $(0.961)$ \\
\hline$\Delta$ Fixed Capital & $11.12 * * *$ & $(1.483)$ & $9.442 * * *$ & $(1.585)$ & $7.818 * * *$ & $(0.795)$ \\
\hline$\Delta$ Government Expenditure & $-10.5 * * *$ & $(2.005)$ & $-10.75 * * *$ & $(2.344)$ & $-4.87 * * *$ & $(1.034)$ \\
\hline$\Delta$ Population Growth & 4.876 & $(4.891)$ & 15.07 & $(9.361)$ & -0.209 & $(0.295)$ \\
\hline$\Delta$ Financial Development & $0.777 *$ & $(1.595)$ & -0.752 & $(1.720)$ & $-0.94 * * *$ & $(0.361)$ \\
\hline$\Delta$ Financial Development Sq & $-0.289 *$ & $(0.669)$ & -0.858 & $(0.801)$ & $-0.43 * * *$ & $(0.104)$ \\
\hline Intercept & $-2.26 * * *$ & $(0.322)$ & -2.668 & (14.180) & $-5.198 *$ & (3.064) \\
\hline Country & 52 & & 52 & & 52 & \\
\hline Observation & 1,454 & & 1,454 & & 1,454 & \\
\hline Hausman Test & & & $4.15^{\mathrm{a}}$ & & $5.76^{b}$ & \\
\hline $\mathrm{p}$-value & & & 0.656 & & 0.450 & \\
\hline
\end{tabular}

Note: $* * *$, and $* * *$ indicate significance at $10 \%, * *$ at $5 \%$ and $* * *$ at $1 \%$. Estimations are done by using (xtpmg) routine in Stata.

Pooled mean group, mean group, and dynamic fixed effects, all controlling for country and time effects. While the first panel (LR) shows

long-run effects. The second panel reports both short-run effects (SR) and the speed of adjustment (ec).Hausman test is indicating that

PMG is consistent and efficient estimation than MG and DFE estimation. The lag structure is ARDL $(1,1,1,1,1,1)$ and the order of variables is: GDP Growth, Trade, Fixed Capital, Government Expenditure, Population, Financial Development and Financial development Square. All the middle income countries, annual data 1980-2008.

${ }^{a}$ PMG is more efficient estimation than MG under null hypothesis.

${ }^{\mathrm{b}} \mathrm{PMG}$ is more efficient estimation than DFE under null hypothesis. 
Table 7: Upper Middle Income Countries with Non-linear Effect of FD

Model: GDPG $=f$ (Trade, Fixed Capital, Government, Population, Financial Development, Financial development Square).

\begin{tabular}{|c|c|c|c|c|c|c|}
\hline \multirow{2}{*}{ Variable } & \multicolumn{2}{|c|}{ Pooled Mean Group } & \multicolumn{2}{|l|}{ Mean Group } & \multicolumn{2}{|c|}{ Dynamic Fixed Effect } \\
\hline & Coef. & Std. Error & Coef. & Std. Error & Coef. & Std. Error \\
\hline \multicolumn{7}{|l|}{ Long-Run Coefficients } \\
\hline Trade & $2.550 * * *$ & $(0.715)$ & $4.637 * *$ & $(2.296)$ & $3.878 * * *$ & $(0.983)$ \\
\hline Fixed Capital & $-1.505^{* *}$ & $(0.744)$ & -0.0252 & (2.044) & -0.963 & $(1.115)$ \\
\hline Government Expen. & $-3.484 * * *$ & $(0.754)$ & $-9.81 * * *$ & $(2.827)$ & $-3.03 * * *$ & $(0.991)$ \\
\hline Population Growth & -0.314 & $(0.296)$ & -1.161 & $(2.308)$ & 0.314 & $(0.428)$ \\
\hline Financial Development & $0.443 * *$ & $(0.201)$ & -1.494 & $(2.068)$ & $-0.575^{*}$ & $(0.296)$ \\
\hline Financial Development Sq & $-0.195 * * *$ & $(0.064)$ & -0.267 & $(1.161)$ & $-0.0873 *$ & $(0.094)$ \\
\hline Error correction Coefficient & $-0.938 * * *$ & $(0.067)$ & $-1.21 * * *$ & $(0.056)$ & $-0.85 * * *$ & $(0.037)$ \\
\hline$\Delta$ Trade & -0.983 & $(2.808)$ & 1.936 & (3.244) & -1.033 & $(1.459)$ \\
\hline$\Delta$ Fixed Capital & $14.79 * * *$ & $(2.376)$ & $12.54 * * *$ & $(2.585)$ & $10.17 * * *$ & $(1.164)$ \\
\hline$\Delta$ Government Expenditure & $-10.92 * * *$ & $(2.500)$ & $-11.6 * * *$ & $(2.662)$ & $-4.85 * * *$ & $(1.543)$ \\
\hline$\Delta$ Population Growth & 8.343 & (11.200) & 9.162 & $(13.300)$ & -0.438 & $(0.520)$ \\
\hline$\Delta$ Financial Development & 1.197 & $(1.037)$ & 0.857 & $(1.912)$ & $-1.187 * *$ & $(0.579)$ \\
\hline$\Delta$ Financial Development Sq & -0.128 & $(0.665)$ & 0.262 & $(0.789)$ & $-0.380 * *$ & $(0.154)$ \\
\hline Intercept & $7.543 * * *$ & $(0.703)$ & 8.917 & (19.690) & -1.546 & $(4.795)$ \\
\hline Country & 23 & & 23 & & 23 & \\
\hline Observation & 644 & & 644 & & 644 & \\
\hline Hausman Test & & & $5.14^{\mathrm{a}}$ & & $5.22^{\mathrm{b}}$ & \\
\hline $\mathrm{p}$-value & & & 0.525 & & 0.515 & \\
\hline
\end{tabular}

Note:*, **, and $* * *$ indicate significance at $10 \%, * *$ at $5 \%$ and $* * *$ at $1 \%$. Estimations are done by using (xtpmg) routine in Stata. Pooled mean group, mean group, and dynamic fixed effects, all controlling for country and time effects. While the first panel (LR) shows long-run effects. The second panel reports both short-run effects (SR) and the speed of adjustment (ec).Hausman test is indicating that PMG is consistent and efficient estimation than MG and DFE estimation. The lag structure is ARDL $(1,1,1,1,1,1)$ and the order of variables is: GDP Growth, Trade, Fixed Capital, Government Expenditure, Population Growth , Financial Development and Financial development Square. Upper Middle Income Countries, annual data 1980-2008.

${ }^{a}$ PMG is more efficient estimation than MG under null hypothesis.

${ }^{\mathrm{b}} \mathrm{PMG}$ is more efficient estimation than DFE under null hypothesis. 
Table 8: Lower Middle Income Countries with Non-linear Effect of FD

Model: GDPG $=f$ (Trade, Fixed Capital, Government, Population, Financial Development, Financial development Square).

\begin{tabular}{|c|c|c|c|c|c|c|}
\hline \multirow{2}{*}{ Variable } & \multicolumn{2}{|c|}{ Pooled Mean Group } & \multicolumn{2}{|l|}{ Mean Group } & \multicolumn{2}{|c|}{ Dynamic Fixed Effect } \\
\hline & Coef. & Std. Error & Coef. & Std. Error & Coef. & Std. Error \\
\hline \multicolumn{7}{|l|}{ Long-Run Coefficients } \\
\hline Trade & $3.471 * * *$ & $(0.602)$ & 6.235 & $(4.071)$ & $3.529 * * *$ & $(0.922)$ \\
\hline Fixed Capital & $1.490 * *$ & $(0.601)$ & 1.826 & (1.919) & $1.995 * *$ & $(0.994)$ \\
\hline Government Expen. & $-1.898 * * *$ & $(0.698)$ & -4.061 & $(3.562)$ & $-3.830 * * *$ & $(1.031)$ \\
\hline Population Growth & 0.262 & $(0.249)$ & 1.085 & (1.910) & $0.774 * *$ & $(0.379)$ \\
\hline Financial Development & 0.264 & $(0.175)$ & -4.141 & $(2.830)$ & 0.0137 & $(0.280)$ \\
\hline Financial Development SQ & $-0.102 *$ & $(0.057)$ & -1.471 & $(1.521)$ & $-0.197 * *$ & $(0.081)$ \\
\hline Error correction Coefficient & $-0.86 * * *$ & $(0.057)$ & $-1.14 * * *$ & $(0.056)$ & $-0.75^{* * *}$ & $(0.034)$ \\
\hline$\Delta$ Trade & -2.31 & $(2.035)$ & -0.184 & $(2.792)$ & -0.436 & $(1.285)$ \\
\hline$\Delta$ Fixed Capital & $7.835^{* * *}$ & $(1.560)$ & $6.983 * * *$ & $(1.885)$ & $4.713 * * *$ & (1.123) \\
\hline$\Delta$ Government Expenditure & $-10.09 * * *$ & $(3.206)$ & $-10.00 * * *$ & $(3.672)$ & $-4.905 * * *$ & $(1.383)$ \\
\hline$\Delta$ Population Growth & 3.955 & $(5.212)$ & 19.75 & $(13.200)$ & -0.175 & $(0.356)$ \\
\hline$\Delta$ Financial Development & 0.62 & $(2.797)$ & -2.029 & $(2.692)$ & $-0.838 *$ & $(0.469)$ \\
\hline$\Delta$ Financial Development Sq & -0.669 & (1.134) & -1.747 & $(1.282)$ & $-0.42 * * *$ & $(0.145)$ \\
\hline Intercept & $-8.84 * * *$ & $(0.687)$ & -11.86 & $(20.190)$ & -6.22 & $(4.003)$ \\
\hline Country & 29 & & 29 & & 29 & \\
\hline Observation & 810 & & 810 & & 810 & \\
\hline Hausman Test & & & $1.72^{\mathrm{a}}$ & & $3.43^{b}$ & \\
\hline p-value & & & 0.943 & & 0.753 & \\
\hline
\end{tabular}

Note:*, **, and $* * *$ indicate significance at $10 \%, * *$ at $5 \%$ and $* * *$ at $1 \%$. Estimations are done by using (xtpmg) routine in Stata. Pooled mean group, mean group, and dynamic fixed effects, all controlling for country and time effects. While the first panel (LR) shows long-run effects. The second panel reports both short-run effects (SR) and the speed of adjustment (ec).Hausman test is indicating that PMG is consistent and efficient estimation than MG and DFE estimation. The lag structure is ARDL $(1,1,1,1,1,1)$ and the order of variables is: GDP Growth, Trade, Fixed Capital, Government Expenditure, Population, Financial Development and Financial development Square. Lower Middle Income Countries, annual data 1980-2008.

${ }^{a} \mathrm{PMG}$ is more efficient estimation than MG under null hypothesis.

${ }^{\mathrm{b}} \mathrm{PMG}$ is more efficient estimation than DFE under null hypothesis. 
Table 9: U-Test:

The table reports the results of the Sasabuchi-Lind-Mehlum test for inverse U-shaped relationship. There model have been consider i) Whole Middle Income Country (MIC) ii) Upper Middle Income Country (UMIC) and iii) Lower Middle Income Country (LMIC)

\begin{tabular}{lccc}
\hline & MIC & UMIC & LMIC \\
\hline Slope at $\mathrm{FD}_{\min }$ & $0.74 * * *$ & $0.82^{* * *}$ & $0.92^{* * * *}$ \\
& $(2.36)$ & $(0.07)$ & $(2.34)$ \\
Slope at $\mathrm{FD}_{\text {Max }}$ & $-1.04 * * *$ & $-0.87 *$ & $-1.21^{* * *}$ \\
& $(-2.49)$ & $(-1.32)$ & $(-2.13)$ \\
\hline SLM test for inverse U shape & 2.36 & 1.96 & 2.14 \\
P Value & 0.009 & 0.06 & 0.01 \\
\hline
\end{tabular}

T- Value in parentheses $* * * \mathrm{p}<0.01, * * \mathrm{p}<0.05, * \mathrm{p}<0.1$

Table 10: Results of dynamic panel threshold estimations

\begin{tabular}{lrrrrr}
\hline & MIC & & UMIC & \multicolumn{2}{c}{ LMIC } \\
\hline Coef. & Std. Error & Coef. & Std. Error & Coef. & Std. Error \\
\hline
\end{tabular}

Threshold estimates

$\begin{array}{llll}\hat{\gamma} & 0.915 & 0.918 & 0.433\end{array}$

$95 \%$ Confidence interval $\quad\left[\begin{array}{lll}0.685 & 1.050\end{array}\right] \quad\left[\begin{array}{lll}0.978 & 0.929\end{array}\right] \quad\left[\begin{array}{ll}0.203 & 0.487\end{array}\right]$

Financial Development

\begin{tabular}{|c|c|c|c|c|c|c|}
\hline$\hat{\beta}_{1}$ & $1.430 * * *$ & $(0.488)$ & $3.214 * * *$ & $(1.148)$ & 0.001 & $(0.447)$ \\
\hline$\hat{\beta}_{2}$ & $-0.718 * * *$ & $(0.195)$ & $-0.984 * * *$ & $(0.263)$ & $-0.855 * * *$ & $(0.344)$ \\
\hline \multicolumn{7}{|l|}{ Impact of covariates } \\
\hline GDP Growth i,t-1 $_{1}$ & $0.232 * * *$ & $(0.040)$ & $0.172 * * *$ & $(0.056)$ & $0.276^{* * *}$ & $(0.052)$ \\
\hline Trade $_{i t}$ & $2.196^{* * *}$ & $(0.629)$ & $2.232 * *$ & $(0.975)$ & $1.725 * *$ & $(0.787)$ \\
\hline Fixed Capital $_{\text {it }}$ & $2.204 * * *$ & $(0.701)$ & $2.512 * *$ & $(1.161)$ & $1.896 * *$ & $(0.814)$ \\
\hline Government Expenditure $_{\text {it }}$ & $-2.365^{* * *}$ & $(0.712)$ & $-3.022 * * *$ & $(1.082)$ & $-2.705 * * *$ & $(0.958)$ \\
\hline Population Growth ${ }_{\text {it }}$ & 1.259 & $(0.991)$ & $3.900 * *$ & $(1.682)$ & 0.238 & $(1.273)$ \\
\hline$\hat{\delta}_{1}$ & $2.856^{* * *}$ & $(0.771)$ & $5.935 * * *$ & $(1.602)$ & -0.843 & $(0.561)$ \\
\hline Observations & & 1454 & & 644 & & 810 \\
\hline$N$ & & 52 & & 23 & & 29 \\
\hline
\end{tabular}




\section{References}

Ahmed, S., (1998). The Legal Environment, Banks, and Long-Run Economic Growth: Comment. Journal of Money Credit and Banking, 30(3), 614-620.

Alfaro, L., Chanda, A., Sebnem, K.O., and Sayek, S. 2004. "FDI and economic growth: the role of local financial markets," Journal of International Economics, 64, 89-112.

Alfaro, L., Chanda, A., Sebnem, K.O., and Sayek, S. 2010. "Does foreign direct investment promote growth? Exploring the role of financial markets on linkages," Journal of Development Economics, 91, 242-256.

Al-Yousif, Y.K. (2002). Financial development and economic growth: another look at the evidence from developing countries. Review of Financial Economics 11 (2), 131-150.

Ang, J.B., and Mckibbin, W.J., (2007). Financial Liberalization, Financial Sector Development and Growth: Evidence from Malaysia. Journal of Development Economics, 84(1), 215-233.

Arcand, J., Berkes, E., Panizza, U., (2012). Too Much Finance? International MonetaryFund.Research Department.

Arellano, M., (2003). Panel Data Econometrics, Oxford University Press.

Arellano, M., and Bond, S., (1991). Some tests of specification for panel data: Monte Carlo evidence and an application to employment equations. The Review of Economic Studies, 58(2), 277-297.

Arellano, M., and O. Bover., (1995). Another Look at The Instrumental Variable Estimation of ErrorComponents Models. Journal of Econometrics, 68, 29-52.

Asteriou, D., and Monastiriotis, V., (2004). What do unions do at the large scale? Macro-economic evidence from a panel of OECD countries. Journal of Applied Economics, 7(1), 27-46.

Baltagi, B., (2008). Econometric analysis of panel data, John Wiley and Sons, Chichester.

Baltagi, BH., Griffin, JM., and Xiong, W., (2000). To pool or not to pool: homogeneous versus heterogeneous estimators applied to cigarette demand. Review of Economics and Statistics 82(1),117-126.

Barro, R.J., (1974). Are government bonds net wealth? Journal of Political Economy, 82, 1095-1117.

Barro, R.J., (1991). Economic Growth in a Cross Section of Countries. Quarterly Journal of Economics, 106, 407-443.

Beck, T., (2008). The Econometrics of Finance and Growth, Palgrave Handbook of Econometrics, 2.

Beck, T., H. Degryse, C. Kneer (2014). Is more finance better? Disentangling intermediation and size effects of financial systems. Journal of Financial Stability 10, 50-64. 
Beck, T., Levine, R., and Loayza, N. (2000a). Finance and the Sources of Growth. Journal of Financial Economics, 58(1), 261-300.

Beck, T., Demirgüç-Kunt, A., \& Levine, R. (2000b), "A New Database on Financial Development and Structure," World Bank Economic Review 14, 597-605.

Bencivenga, V.R. and Smith, B.D., (1991). Financial Intermediation and Endogenous Growth. The Review of Economic Studies, 58(2), 195-209.

Ben-David, D. (1993). Equalizing exchange: Trade liberalization and income convergence. Quarterly Journal of Economics 108(3).

Bezemer, D., M. Grydaki and L. Zhang (2014). Credit Is What Credit Does: A Functional Differentiation of the Credit-Growth Relation. University of Groningen, mimeo.

Bhattacharya, P.C. and Sivasubramanian, M. N. (2003) Financial development and economic growth in India: 1970-1971 to 1998-1999, Applied Financial Economics, 13, pp. 925-929.

Bick, A., 2010. Threshold effects of inflation on economic growth in developing countries. Economics Letters 108 (2), 126-129.

Blackburne, E.F. and Frank, M.W., (2007). Estimation of nonstationary heterogeneous panels. Stata Journal, 7(2), 197-208.

Blundell, R., and Bond, S., (1998). Initial conditions and moment restrictions in dynamic panel data models. Journal of Econometrics, 87(1), 115-143.

Bond, S. R., (2002). Dynamic panel data models: a guide to micro data methods andpractice. Portuguese Economic Journal, 1(2), 141-162.

Borensztein, Eduardo, Jose De Gregorio, and Jong-Wha Lee (1998). "How does foreign direct investment affect economic growth?." Journal of International Economics, 45: 115-135.

Breitung, J. 2000.The local power of some unit root tests for panel data. Advances in Econometrics, Volume 15: Nonstationary Panels, Panel Cointegration, and Dynamic Panels, ed. B. H. Baltagi, 161-178. Amsterdam: JAY Press.

Calderon, C., and Liu, L., (2003). The Direction of Causality between Financial Development and Economic Growth. Journal of Development Economics, 72(1), 321.

Campos, N.F., Kinoshita, Y., (2008). Foreign Direct Investment and Structural Reforms: Evidence from Eastern Europe and Latin America. Washington, D.C.: International Monetary Fund, IMF Institute.

Campos, N.F. and Kinoshita, Y., (2010). Structural Reforms, Financial Liberalization, and Foreign Direct Investment. IMF Staff Papers, 57(2), 326-365. 
Caner, M., Hansen, B.E. (2004). Instrumental variable estimation of a threshold model. Econometric Theory 20(5), 813-843.

Cecchetti, G., Kharroubi, E. (2012). Reassessing the Impact of Finance on Growth. BIS Working Paper No. 381, Bank for International Settlements.

Christopoulos, D.K. and Tsionas, E.G., (2004). Financial Development and Economic Growth: Evidence from Panel Unit Root and Cointegration Tests. Journal of Development Economics, 73(1), 55-74.

Chuah. H. L., and Thai.W., (2004). Financial Development and Economic Growth: Evidence from Causality Tests for the GCC countries. IMF Working Paper.

Dawson, P.J., (2010). Financial Development and Economic Growth: A Panel Approach. Applied Economics Letters, 17(8), 741-745.

Deidda, L. and Fattouh, B., (2002). Non-linearity between finance and growth. Economics Letters, 74(3), 339-345.

Demetriades, P.O. and Hussein, K.A. (1996). Does Financial Development Cause Economic Growth? Time-Series Evidence from 16 Countries. Journal of Development Economics, 51(2), 387-412.

Demetriades, P. and Law, S. H., (2006). Finance, Institutions and Economic Growth. International Journal of Finance and Economics, 11(3), 245-260.

Demetriades, Panicos O and Luintel, Kul B (1996). "Financial Development, Economic Growth and Banker Sector Controls: Evidence from India," Economic Journal, 106(435), 359-74.

Demetriades, P. and Rousseau, P. L., (2011). The changing face of financial development. In $M M F$ Conference, University of Birmingham.

Demirguc-Kunt, Asli and Levine, Ross (1999). "Bank-based and Market-based Financial Systems:Cross-Country Comparisons", World Bank Policy Research Working Paper 2143.

Devarajan, S., Swaroop, V., and Zou, H. (1996) The composition of public expenditure and economic growth, Journal of Monetary Economics, 37, 313-44.

Dollar, D. (1992). Outward-oriented developing economies really do grow more rapidly: Evidence from 95 LDCs, 1976-85. Economic Development and Cultural Change 523-544.

Dollar, D. and A. Kraay (2003). Institutions, trade, and growth. Journal of International Economics, 50, 133-162.

Easterly, W. and Levine, R., (2001). What have we learned from a decade of empirical research on growth? It's Not Factor Accumulation: Stylized Facts and Growth Models. World Bank Economic Review, 15(2), 177-219.

Easterly, W., R. Islam and J. E. Stiglitz (2000). Explaining growth volatility. The World Bank, mimeo. 
Eberhardt, M., (2012). Estimating panel time-series models with heterogeneous slopes. Stata Journal, 12(1), 61-71.

Eberhardt, M., and Teal, F., (2011). Econometrics for Grumblers: A New Look At The Literature On Cross-Country Growth Empirics. Journal of Economic Surveys, 25(1), 109-155.

Edwards, S. (1998). Openness, productivity and growth: What do we really know? Economic Journal, $108,383-398$.

Ericsson, N. R., Irons, J. S., and Tryon, R. W., (2001). Output and inflation in the long run. Journal of Applied Econometrics, 16 (3), 241-253.

Ethier, Wilfred J. (1982). National and international returns to scale in the modern theory of international trade. American Economic Review, 72, 389-405.

Favara, G., (2003). An Empirical Reassessment of the Relationship between Finance and Growth. IMF Working Paper No. 03/123.

Frankel, J., and D. Romer. (1999). Does trade cause growth? American Economic Review, 89,379-399.

Fry, M.J., (1997). In Favour of Financial Liberalisation. The Economic Journal. 107(442), 754-770.

Futagami, K., Morita, Y., and Shibata, A. (1993). Dynamic analysis of an endogenous growth model with public capital, Scandinavian Journal of Economics, 95, 607-25.

Gavin, M.K., Hausmann, R., (1996). The Roots of Banking Crises: The Macroeconomic Context. Inter-American Development Bank, Office of the Chief Economist.

Ghosh, Sugata and Andros Gregoriou (2008). 'The Composition of Government Spending and Growth: Is Current or Capital Spending Better?' Oxford Economic Papers, 60, 484-516.

Goldsmith, R.W., (1969). Financial Structure and Development, New Haven: Yale University Press.

Greenwood, J., and Jovanovic, B., (1990). Financial Development, Growth, and the Distribution of Income. London, Ont., Canada: Dept. of Economics, Social Science Centre, University of Western Ontario.

Greenwood, J. and Smith, BD., (1997). Financial Markets in Development, and the Development of Financial Markets.Journal of Economic Dynamics and Control, 21(1), 145-181.

Gries, T., Kraft, M., and Meierrieks, D., (2009). Linkages between Financial Deepening, Trade Openness and Economic Development: Causality Evidence from Sub-Saharan Africa., World Development 37(12), 1849-1860.

Gurley, J.G. and Shaw, E.S., (1955). Financial Aspects of Economic Development. The American Economic Review, 45(4), 515-538. 
Halicioglu Odedokun, M. (1989). The Effects of Systematic and Surprise Fiscal Policy Actions in a Developing Economy: Evidence from Nigeria. Eastern Africa Economic Review, 5(2), 122-132.

Hansen, B.E. (1999). Threshold effects in non-dynamic panels: estimation, testing, and inference. Journal of Econometrics 93 (2), 345-368.

Hansen, B.E. (2000). Sample splitting and threshold estimation. Econometrica 68 (3), 575-603.

Harrison, A. (1996). Openness and growth: A time-series, cross-country analysis for developing countries. Journal of Development Economics 48, 419-447.

Hassan, M. K., Sanchez, B., and Yu, J. S. (2011). Financial development and economic growth: New evidence from panel data. Quarterly Review of Economics and Finance 51(1), 88-104.

Hauner, D. (2009), "Public Debt and Financial Development", Journal of Development Economics, 88(1), 171-183.

Holly, S. and Raissi, M., (2009). The Macroeconomic Effects of European Financial Development: A Heterogeneous Panel Analysis. Working Paper (No. 1.4). DIW Berlin, German Institute for Economic Research.

Huang, H.C., Lin, S.C. (2009). Non-linear finance-growth nexus. Economics of Transition 17, 439466.

Im, K. S., M. H. Pesaran, and Y. Shin (2003). “Testing for unit roots in heterogeneous panels." Journal of Econometrics 115: 53-74.

Irwin, D. A., and Terviö, M. (2002). Does trade raise income?: Evidence from the twentieth century. Journal of International Economics, 58(1), 1-18.

Johansen, S., (1995). Likelihood-Based Inference in Cointegrated Vector Autoregressive Models. Oxford; New York: Oxford University Press.

Kar, M., Nazlioglu, S. and Agir, H., (2011). Financial development and economic growth nexus in the MENA countries: Bootstrap panel granger causality analysis. Economic Modelling, 28(1), 685693.

Karavias, Yiannis and Elias Tzavalis 2 Testing for unit roots in short panels allowing for a structural break" Computational Statistics and Data Analysis 76 (2014) 391-407.

Khan, M.S., and Senhadji, A.S., (2003). Financial Development and Economic Growth: A Review and New Evidence. Journal of African Economies, 12(2), 89-110.

King, R.G. and Levine, R., (1993a). Finance, Entrepreneurship, and Growth: Theory and Evidence. Journal of Monetary Economics, 32(3), 513.

King, R.G. And Levine, R., (1993b). Finance and Growth: Schumpeter Might be Right. The Quarterly Journal of Economics, 108(3), 717-737. 
Kiviet, J., (1995). On bias, inconsistency, and efficiency of various estimators in dynamic panel data models. Journal of Econometrics, 68(1), 53-78.

Kremer, S., Bick, A., Nautz, D. (2013). Inflation and growth: new evidence from a dynamic panel threshold analysis. Empirical Economics 44 (2), 861-878.Kuznets, S. (1955). "International Differences in Capital Formation and Financing," in: Capital Formation and Economic Growth, National Bureau of Economic Research, Inc., 19-111.

Law, S.H., N. Singh (2014). Does too much finance harm economic growth? Journal of Banking and Finance 41, 36-44.

Law, S. H., Azman-Saini, W. N. W., \& Ibrahim, M. H. (2013). Institutional quality thresholds and thefinance-Growth nexus. Journal of Banking \& Finance,37(12), 5373-5381.

Levin, A., C.-F. Lin, and C.-S. J. Chu. 2002. Unit root tests in panel data: Asymptotic and finite-sample properties. Journal of Econometrics 108: 1-24.

Levine, R., (1997). Financial Development and Economic Growth: Views and Agenda. Journal of Economic Literature, 352(2), 688-726.

Levine, R., (2005). Finance and growth: theory and evidence. Handbook of Economic Growth, 1(12) 865-934.

Levine, R. and Zervos, S., (1998). Stock Markets, Banks, and Economic Growth. The American Economic Review, 88(3), 537-558.

Liang, Q., and Teng, J.Z., (2006). Financial Development and Economic Growth: Evidence from China. China Economic Review, 17(4), 395-411.

Lind J.T. and Mehlum H., (2010).With Or Without U? The Appropriate Test for a U-Shaped Relationship. Oxford Bulletin of Economics and Statistics, 72(1), 109-118.

Loayza, N.V. and Rancière, R., (2006). Financial Development, Financial Fragility, and Growth. Journal of Money, Credit and Banking, 38(4), 1051-1076.

Lucas, R.E. (1988). On the mechanics of economic development. Journal of Monetary Economics 22, 3-42.

Luintel, K. B., and Khan, M., (1999). A Quantitative Reassessment of the Finance-Growth Nexus: Evidence from A Multivariate VAR. Journal of Development Economics. 60(2), 381-405.

Mankiw, N. Gregory, David Romer, and David Weil (1992). "A Contribution to the Empirics" of Economic Growth.” Quarterly Journal of Economics, 107, 407-438.

McKinnon, R. I., (1973). Money and Capital in Economic Development, Washington: Brookings Institution Press. 
Odedokun, M. O. (1996), Alternative econometric approaches for analyzing the role of the financial sector in economic growth: time-series evidence from LDCs. Journal of Development Economics 50, 119 -146.

Owen, A.L., J. Temesvary (2014). Heterogeneity in the growth and finance relationship: How does the impact of bank finance vary by country and type of lending? International Review of Economics and Finance 31, 275-288.

Ozturk, Ilhan (2008). "Financial Development And Economic Growth: Evidence From Turkey," Applied Econometrics and International Development, Euro-American Association of Economic Development, 8(1), pages 85-98.

Patrick, H.T. (1966). Financial development and economic growth in underdeveloped countries. Economic Development and Cultural Change 14, 174-189.

Pesaran, H., (1997). The Role of Econometric Theory in Modelling the Long Run, Economic Journal, 107(440), 178-191.

Pesaran, H. and Smith, R., (1995). Estimating Long-Run Relationships from Dynamic Heterogeneous Panels, Journal of Econometrics, 68(1),79-113.

Pesaran, H. and Shin, Y., (1999). An Autoregressive Distributed Lag Modelling Approach to Cointegration in Econometrics and Economic Theory in the 20th Century, The Ragnar Frisch Centennial Symposium Cambridge University Press, chapter, 4, 371-413.

Pesaran, M.H., Shin, Y. and Smith, R.P., (1999). Pooled Mean Group Estimation of Dynamic Heterogeneous Panels. Journal of the American Statistical Association, 94(446), 621-634.

Philipps, P., and Bruce, H., (1990). Statistical Inference in Instrumental Variables Regression with I(1) Processes. The Review of Economic Studies 57(1), 99-125.

Rajan, R.G., and Zingales, L., (1998). Financial Dependence and Growth. The American Economic Review, 88(3), 559-586.

Rioja, F., Valev, N. (2004a). Finance and the sources of growth at various stages of economic development. Economic Inquiry, 42, 127-140.

Rioja, F., Valev, N. (2004b). "Does one size fit all? A reexamination of the finance and growth relationship," Journal of Development Economics 74(2), 429-447.

Robinson, J. (1952). The Generalization of the General Theory, the Rate of Interest and Other Essays. Macmillan, London, pp. 67-142.

Romer, P.M. (1986). Increasing returns and long run growth. Journal of Political Economy 94 (5), 1002-1037.

Roodman, D., (2006). How to do xtabond2: An introduction to Difference and System GMM in Stata. Center for Global Development working paper, (103). 
Roubini, N. and Sala-I-Martin, X., (1992). Financial Repression and Economic Growth. Journal of Development Economics, 39(1), 5-30.

Rousseau, P. L., and Wachtel, P., (2002). Inflation Thresholds and the Finance-Growth Nexus, Journal of International Money and Finance, 21(6), 777-793.

Rousseau, P. L. and Wachtel, P., (2011). What is happening to the impact of financial deepening on economic growth? Economic Inquiry, 49(1), 276-288.

Sachs, J., and A. Warner. (1995). Economic reform and the process of global integration. Brookings Papers on Economic Activity, 1-118.

Savvides, A., (1995). Economic Growth in Africa. World Development, 23(3), 449-458.

Schumpeter, J.A., and Opie, R., (1934).The theory of economic development; an inquiry into profits, capital, credit, interest, and the business cycle, Cambridge, Mass.: Harvard University Press.

Shaw, E. S., (1973). Financial Deepening in Economic Development. New York: Oxford University Press.

Simon, Julian L. (1996), The Ultimate Resource 2, Princeton NJ: Princeton University Press.

Solow, Robert (1957), "Technical Change and the Aggregate Production Function," Review of Economics and Statistics, 70-92.

Sundarajan.V., and Balino, T. J. (1991). Banking Crises: Cases and Issues. International Monetary Fund.

$\mathrm{Xu}$, Z. (2000). Financial development, investment, and economic growth. Economic Inquiry 38 (2), 331-344. 